\title{
SHADES OF BROWN: THE LAW OF SKIN COLOR
}

\author{
TRINA JONES $\dagger$
}

Because antidiscrimination efforts have focused primarily on race, courts have largely ignored discrimination within racial classifications on the basis of skin color. In this Article, Professor Jones brings light to this area by examining the historical and contemporary significance of skin color in the United States. She argues that discrimination based on skin color, or colorism, is a present reality and predicts that this form of discrimination will assume increasing significance in the future as current understandings of race and racial classifications disintegrate. She maintains that the legal system must develop a firm understanding of colorism in order for the quest for equality of opportunity to succeed.

Introduction

I. Distinguishing Race and Skin Color ........................................1493

II. Color Distinctions Through the Lens of Time .........................1499

A. Before the Civil War: 1607-1861 ......................................1500

1. The Upper South ..................................................... 1503

2. The Lower South ....................................................1506

B. After the Civil War: 1865-2000 ......................................... 1511

1. Colorism Within the White Community...................1511

2. Colorism Within the Black Community ....................1515

Copyright $@ 2000$ by Trina Jones

$\dagger$ Associate Professor of Law, Duke University. I would like to thank God, my family, Margaret Ackerley, Najla Al-Radwan, and Loris S. Ray for their loving support and encouragement. I would also like to thank Catherine Admay, Leonard Baynes, Sara Sun Beale, Robert Belton, Tonya Brito, James Coleman, Paul Haagen, Angela Harris, Donald Horowitz, Jeff Powell, Girardeau Spann, and Laura Underkuffler for providing helpful comments on earlier drafts of this Article. For their excellent research and editorial assistance, I am indebted to Nicole Becton, Julie Chambers, Shymeka Hunter, Alina Kantor, Inna Kantor, Mariya Seacrest, Stacey-Ann Taylor, and the editorial staff of the Duke Law Journal. This Article benefited from comments by participants at the Stanford/Yale Junior Faculty Forum (May 12-13, 2000), the Southwestern/Southeastern Law Faculty of Color Regional Conference (March 30-April 1, 2000), and the Northeastern People of Color Legal Scholarship Conference (April 13-15, 2000). 
3. The Multiracial Category Movement and

Colorism

C. The Social Psychology of Contemporary Black-

White Colorism

III. Color in Contemporary Law.

A. Statutory Support for Color Claims................................1532

B. Substantive Content of Color Claims ..............................1537

C. Race, Color, Mixed Racial Identity and

Employment Discrimination Law.

1. Analytical Frameworks Under Title VII and

Section 1981

2. Establishing a Prima Facie Case

3. The Defendant's Response and the Relevance of Color

D. Colorism and the Quest for Equality of

Opportunity

\section{INTRODUCTION}

On the Saturday evening following my mother's recent marriage, old friends and new gathered at a local restaurant to celebrate the occasion. While standing in the buffet line, I turned to introduce my new step-niece, Aaliyah (age 4), to the son of a family friend, LaShaun (age 5). Immediately following the introduction, LaShaun, who is clearly outgoing and charismatic, looked up at me with the innocent honesty of a child and said, "I know another Aaliyah at my school, but she's brown."

The first thing LaShaun, whose skin is a rich Michael Jordan chocolate, noticed about Aaliyah was her light golden brown skin. LaShaun did not create or invent these differences. Without deliberate or conscious design, his statement merely reflects the fact that he operates in a social context where people learn early on that color is significant. $^{2}$ Although some people may claim that color differences

1. Conversation Between Trina Jones, LaShaun Foster, Aaliyah Campbell, and Dawn Foster Williams (May 8, 1999).

2. Psychologists have noted that very early in life (between the ages of three and five), children notice skin color in the same way that they notice differences in hair color and eye color. See Marguerite N. Alejandro-Wright, The Child's Conception of Racial Classification: A Socio-Cognitive Developmental Model, in Beginnings: THE Social AND AfFective 
within racial groups are without meaning and that people do not notice or care about fine differences in skin pigmentation, the observations of a five-year-old child belie these statements. And so does history. ${ }^{3}$

This Article examines the prejudicial treatment of individuals falling within the same racial group on the basis of skin color in the context of antidiscrimination law. ${ }^{4}$ In a 1982 essay, Alice Walker called this prejudicial treatment "colorism." Although this terminology appears to be relatively new, colorism is not a recent invention. In the United States, this form of discrimination dates back at least as far as the colonial era. ${ }^{6}$ Yet, notwithstanding its long existence, colorism is often overshadowed by, or subsumed within, racism. As a result, courts are either unaware of the practice or tend to minimize its im-

DEVELOPMENT OF BLACK CHILDREN 185, 186 (1985). They may not, however, understand the social meaning of skin color until they are much older. See id. at 190 (suggesting that there is an "age-related developmental progression to children's conception of racial categories"). This understanding may occur as early as the age of four, but it usually happens around the age of six or seven. See Kathy Russell et Al., THe Color Complex: THE Politics of Skin Color AMONG AFRICAN AMERICANS 65 (1992). But see Alejandro-Wright, supra, at 192 (noting that children do not show a sophisticated understanding of racial categories until age 10). Thus, although it certainly appeared from his tone of voice and demeanor that LaShaun was making a value judgment based upon skin color, it is also possible that he was merely making an observation about superficial physical differences between the two young girls.

3. See infra Parts II.A and II.B.

4. For insightful investigations of color discrimination, see generally COLOR AND RACE (John Hope Franklin ed., 1968) (discussing the significance of color differences in the global community); Lawrence Otis Graham, Our Kind of People: Inside America's Black UPPER CLASS (2000) (examining, among other things, color dynamics within some of America's wealthiest Black families); RUSSELL ET AL., supra note 2 (containing comprehensive analyses of intraracial colorism in the Black community); SKIN DEEP: WOMEN WRITING ON COLOR, CUlTuRE, AND IDENTITY (Elena Featherston ed., 1994) (including essays in which women share their personal experiences with colorism); Leonard Baynes, If It's Not Just Black and White Anymore, Why Does Darkness Cast a Longer Discriminatory Shadow than Lightness? An Investigation and Analysis of the Color Hierarchy, 75 DENV. U. L. REV. 131 (1997) (investigating whether darker-skinned people of color face more discrimination than those with lighter complexions); Ronald Turner, The Color Complex: Intraracial Discrimination in the Workplace, 46 LABOR L.J. 678 (1995) (analyzing cases involving intraracial colorism in the workplace). Colorism within the Black community has been extensively documented in African-American literature and film. See, e.g., WALlaCe THURMAN, THE BlaCKER THE BERRY (Simon \& Schuster 1996) (1929) (Harlem Renaissance novel chronicling the trials of a Black woman who is too dark for her lighter-skinned family); DOROTHY WEST, THE WEDDING (1996) (examining, among other things, color issues within a black bourgeois community on Martha's Vineyard); SCHOOL DAZE (40 Acres and a Mule 1987) (exploring, through the medium of film, intraracial social divisions, including color differences, within all-black colleges).

5. Alice WALKer, If the Present Looks Like the Past, What Does the Future Look Like? (1982), in IN SEARCH OF OUR Mother's Gardens 290, 290-91 (1983) ("Colorism-in my definition, prejudicial or preferential treatment of same-race people based solely on their color ... impedes us.").

6. See discussion infra Part II.A. 
portance. ${ }^{7}$ This state of affairs is unfortunate because, as I demonstrate in this Article, color differences are still frequently used as a basis for discrimination independently of racial categorization. ${ }^{8}$

The analysis proceeds in three parts. Part I distinguishes colorism from racism. Because the ultimate result of race-mixing was the creation of tone or hue variations within racial groups, Part II explores the history of miscegenation in this country in order to demonstrate how society has used skin color to demarcate lines between racial groups and to determine the relative position and treatment of individuals within racial categories. This history illuminates contemporary discrimination on the basis of color. Part III examines the judicial response to contemporary claims based on color and explains why courts can and should permit color claims in the context of antidiscrimination law. Part III also investigates the suggestion that racial classification may become increasingly difficult in the future as the acceptability of the one-drop rule declines and as race-mixing increases. Assuming that there is merit to this suggestion, Part III probes whether legal recognition of claims based upon skin color will provide suitable redress for discrimination against persons who are neither visibly White nor visibly Black. ${ }^{9}$

My hope is that this Article will assist in the development of a more nuanced understanding of the intricate ways in which people discriminate in this country. More specifically, by engaging in this investigation, I seek to prevent the law from becoming a source of injustice by showing how progress towards equality of opportunity may be overstated if colorism is ignored. Briefly, in the aftermath of the civil rights movement, employers have hired increasing numbers of Blacks into positions not previously available to them. The increasing number of Blacks in these positions suggests racial progress. Studies show, however, that Blacks in positions of prominence and authority

7. See discussion infra Part III.A.

8. See infra Parts I, II.B, and II.C.

9. In this Article I shall use the word "Black" in lieu of "African-American" to underscore the importance of skin color in the construction of racial classifications in the United States. I do not, however, mean to suggest that being Black is merely a question of skin color. To reflect my belief that Blacks constitute a specific group with a shared (though not monolithic) history, culture, and experience, I shall capitalize the letter "B" and use the word Black as a proper noun. See Catherine MacKinnon, Editor's Note to Feminism, Marxism, Method, and the State: An Agenda for Theory, 7 SIgns: J. WOMEN CUlTuRE \& SOC'Y, 515, 516 (1982) (stating that "Black" should not be regarded as "merely a color of skin pigmentation, but as a heritage, an experience, a cultural and personal identity, the meaning of which becomes specifically stigmatic and/or glorious and/or ordinary under specific social conditions"). 
tend to be lighter-skinned. ${ }^{10}$ Thus, some employers may be hiring only a subset of the Black population, a subset selected, in part, based on skin color. Because some Blacks are being denied access to employment opportunities due to colorism, the appearance of progress is more limited than we might assume. ${ }^{11}$ Legal recognition of color claims is one way to begin redressing this situation.

10. Numerous sociological studies have documented that lighter-skinned Blacks tend to fare better socially, educationally, economically, and politically than darker-skinned Blacks. See, e.g., Michael G. Hughes \& Bradley R. Hertel, The Significance of Color Remains: A Study of Life Chances, Mate Selection, and Ethnic Consciousness Among Black Americans, 68 Soc. FORCES 1105, 1116-17 (1990) (finding that "blacks with lighter skin tones have higher socioeconomic status, have spouses higher in socioeconomic status, and have lower black consciousness than those with dark skin"); Verna M. Keith \& Cedric Herring, Skin Tone and Stratification in the Black Community, 97 AM. J. OF Soc. 760, 777 (1991) (finding, among other things, that lighter-skinned Blacks are likely to have higher incomes, greater educational achievements, and higher-status jobs than darker-skinned Blacks); Nayda Terkilsden, When White Voters Evaluate Black Candidates: The Processing Implications of Candidate Skin Color, Prejudice, and SelfMonitoring, 37 AM. J. OF POL. SCIENCE 1032 passim (1993) (reporting results of a study in which White respondents evaluated a fictitious dark-skinned Black gubernatorial candidate much more negatively than his light-skinned Black peer).

While it is true that these disparities may result in part from the fact that some lighterskinned Blacks may have received certain inherited advantages, (i.e., social, educational, and economic benefits passed down generationally from their ancestors), there is also evidence to support that contemporary colorism accounts for these differences. Compare Elizabeth I. Mullins \& Paul Sites, The Origins of Contemporary Eminent Black Americans: A Three-Generation Analysis of Social Origin, 49 AM. Sociological REV. 672, 683 (1984) (reporting that many upper-class Blacks have ancestors with lighter skin tones and higher occupational and educational achievements, but positing that the gains of the civil rights movement may soon change "the origins and characteristics of blacks identified as eminent") with Hughes \& Hertel, supra. Notably, in 1990, Hughes and Hertel found that even when one controls for socioeconomic background, light-skinned Blacks did better educationally and occupationally than their darker peers. See Hughes \& Hertel, supra, at 1112-13. Hughes and Hertel determined that the ratio of difference in earnings between light-skinned and dark-skinned Blacks was proportional to that between Whites and Blacks. See id. For every 72 cents a dark-skinned Black made, a lightskinned Black earned a dollar. See id. Similarly, in 1991, Keith and Herring found that:

Skin tone was consistently a more powerful determinant of such stratification outcomes as occupation and personal and family income than was parental socioeconomic status. Also, darker-skinned respondents . . . were about twice as likely to report that they had been the victims of discrimination within the last month than were those with light skin complexions. . . . These facts support the view that differential treatment (i.e., greater discrimination against darker blacks) by whites as well as other blacks continues to occur within this era; thus, it is clear that intraracial inequality has been perpetuated and created anew within the last quarter of the 20th century.

Keith \& Herring, supra, at 775. Although the effects of class may deserve further legal and sociological analysis, this Article focuses on the significant role of color as a basis for discrimination.

11. This problem is not just a contemporary phenomenon. As I demonstrate in Part II.B.2, throughout history skin color differences have played a powerful role in determining the allocation of benefits among Blacks even within the Black community. 
It is important to note that the analysis contained herein focuses on color dynamics among Black Americans. Although some scholars have criticized the tendency to analyze racial issues in terms of a Black/White dichotomy, ${ }^{12}$ I have chosen to concentrate on the Black community in order to limit the magnitude of this project without sacrificing its utility. In addition, this focus allows me to probe more directly the peculiar symbolism of black and white as colors. This symbolism suggests that although colorism is an important element of racism, it is equally its own distinct phenomenon. Finally, although I do not wish to endorse the reduction of race relations to a Black/White paradigm, I have chosen to focus on the dynamics of the racial group with which I am most familiar. I recognize that similar issues concerning skin color exist within Native American, AsianAmerican, and Latino communities, ${ }^{13}$ and believe that issues peculiar to those communities merit detailed study. Although such analysis is beyond the scope of this initial project, I hope this Article will nonetheless be of assistance to scholars in future investigations involving questions specific to other racial groups. ${ }^{14}$

12. For a critical analysis of the tendency to analyze racial issues in terms of a Black/White dichotomy, see, for example, Rachel Moran, What if Latinos Really Mattered in the Public Policy Debate?, 85 CAL. L. REV. 1315, 1316 (1997) (stating that "even after reading three papers in a symposium devoted to Latinos, [the author] was left with the odd impression that Latinos generally remain shadowy figures"); Juan F. Perea, The Black/White Binary Paradigm of Race: The "Normal Science" of American Racial Thought, 85 CAL. L. REV. 1213, 1213 (1997) (arguing that the Black/White paradigm distorts history and marginalizes the experiences of non-Black people of color in racial discourse); Deborah Ramirez, Multicultural Empowerment: It's Not Just Black and White Anymore, 47 STAN. L. REV. 957, 962-63 (1995) (discussing the increasing range of racial and ethnic heritages among people of color); Frank H. Wu, Changing America: Three Arguments About Asian Americans and the Law, 45 AM. U. L. REV. 811, 812 (1996) (arguing that the situation of Asian-Americans "demonstrate[s] that color-blindness is a myth").

13. See, e.g., Carlos H. Arce \& Edward Murguia, Phenotype and Life Chances Among Chicanos, 9 HispaniC J. BeHAV. SCI. 19, 29 (1987); Christina Gomez, The Continual Significance of Skin Color: An Exploratory Study of Latinos in the Northeast, 22 HisPANIC J. BEHAV. SCI. 94, 94 (2000) (finding that having dark skin negatively affects wages of Latino men in the Northeast); Edward E. Telles \& Edward Murguia, Phenotypic Discrimination and Income Differences Among Mexican Americans, 71 SOC. SCI. Q. 682, 682-83 (1990) (finding that Mexican Americans with a European physical appearance enjoy a higher socioeconomic status than Mexican Americans with an indigenous Native American physical appearance); see also Kevin R. Johnson, "Melting Pot" or "Ring of Fire"?: Assimilation and the Mexican American Experience, 10 LA RAZA L.J. 173, 205-07 (1998) (discussing intragroup discrimination among Latinos on the basis of physical appearance).

14. Color issues in Native American, Asian-American, and Latino communities are not unrelated to issues involving Black Americans because: (1) all of these communities share a history of European colonialism in which racism operated to privilege Europeans at the expense of various non-European societies; and (2) all of these communities have in common the color symbolism of light versus dark (indeed this color symbolism may arise independently of European colonialism in Japan and perhaps other Asian countries). See JOHN HOPE FRANKLIN \& 


\section{Distinguishing RACE AND SKIN COLOR}

Race and skin color are distinct phenomena that sometime overlap. Because people are not accustomed to thinking of these concepts separately, I pause here to discuss their relationship. My starting premise is that both race and skin color are social constructions; ${ }^{15}$ their importance comes from the salience that we give them. ${ }^{16}$ Scientific literature supports this view. Indeed, many scientists have concluded that biological races do not exist. ${ }^{17}$ There are few, if any, genetic characteristics possessed exclusively by all Blacks and, similarly, few, if any, genetic characteristics possessed exclusively by all Whites. ${ }^{18}$ Moreover, the genetic variation between racial groups is

Alfred A. Moss, Jr., From Slavery to Freedom 27-56 (7th ed. 1994) (discussing color symbolism in Japan and Latin American countries prior to European colonization).

15. By this, I mean that they are constantly evolving products of the ways in which society construes group differences and attaches meaning to those differences. Professor López employs a similar understanding. He defines race as

a vast group of people loosely bound together by historically contingent, socially significant elements of their morphology and/or ancestry .... Race is neither an essence nor an illusion, but rather an ongoing, contradictory, self-reinforcing process subject to the macro forces of social and political struggle and the micro effects of daily decisions.

Ian F. Haney López, The Social Construction of Race: Some Observations on Illusion, Fabrication, and Choice, 29 HARV. C.R.-C.L. L. REV 1, 7 (1994).

16. See id. at 11-16 (situating the origin of "race" within a historical and social context). It is to this sociopolitical concept of race that I refer throughout this Article.

17. See Richard C. Lewontin, The Apportionment of Human Diversity, 6 EvOluTIONARY BIOLOGY 381, 397 (Theodosius Dobzhansky et al. eds., 1972) (concluding that because racial classifications do not reflect fundamental genetic differences, biologists should abandon talk of biological races); see also St. Francis College v. Al-Khazraji, 481 U.S. 604, 609 n.4 (1987) (citing sources to support that some scientists have concluded that racial classifications are sociopolitical rather than biological constructs). But see Masatoshi Nei \& Arun K. Roychoudhury, Genetic Relationship and Evolution of Human Races, 14 Evolutionary Biology 1, 11, 41 (Max K. Hecht et al. eds., 1982) (noting that "while the interracial genetic variation is small ... the genetic differentiation is real and generally statistically highly significant" and that "the racial differences in many morphological characters have a genetic basis"). For insightful analyses and critiques of the scientific evidence, see KWAME ANTHONY APPIAH, IN MY FATHER'S HOUSE: AFRICA IN THE PHILOSOPHY OF CUlTURE 35-39 (1992); López, supra note 15, at 11-16.

The conclusion that race is not biologically based is underscored by the historical practice of passing (whereby Black individuals with sufficiently light skin concealed their Black heritage and lived within the White community as White), and by the fact that in other countries having dark brown skin does not necessarily mean that one is regarded as a member of the Black race. See, e.g., Eugene Robinson, On the Beach at Ipanema, WASH. Post MAG., Aug. 1, 1999, available in 1999 WL 17016896 (describing an encounter with a dark-skinned Brazilian woman who asserted that she was not considered Black in Brazil even though (per the author's assessment) she would clearly have been Black according to U.S. standards).

18. See generally APPIAH, supra note 17, at 35 (discussing the lack of genetic exclusivity among races); Richard C. LEWONTIN ET AL., NOT IN OUR GENES: BiolOgy, IDEOLOGy, 
small when compared to the genetic variation within those groups. ${ }^{19}$ While morphological differences in hair and skin tone between racial groups are genetically based, scientific inquiry has not demonstrated that the genes responsible for these characteristics also account for "differences between individuals in language, moral affections, aesthetic attitudes, or political ideology." 20

Although standing alone they are meaningless, gross morphological differences (e.g., the broadness of the nose, the fullness of the lips, the curl of the hair) have and continue to be used to delineate racial categories and to assign persons to racial groups. ${ }^{21}$ Among these characteristics, skin color continues to play an important role in indicating an individual's race. The lighter or more white one's skin, the more likely one is to be categorized as Caucasian or White. The darker or more brown one's pigmentation, the more likely one is to be categorized as Negroid or Black. These categories are laden with social meaning. In the United States, being White generally means that one has access to the psychological and economic privileges of Whiteness. ${ }^{22}$ Being Black generally means that one is pegged lower in

AND HUMAN NATURE (1984) (examining and repudiating claims of biological determinism about race).

19. See Nei \& Roychoudhury, supra note 17 , at 11, 40-41.

20. APPIAH, supra note 17, at 35; see also Nei \& Roychoudhury, supra note 17, at 41-42 (noting that "the genetic distance between populations is not always correlated with the morphological distance.... Evidently, the evolutions at the structural gene level and at the morphological level do not obey the same rule").

21. See Thomas F. Gossett, Race: The History of An Idea In AMERICA 69-83 (1997); Ariela J. Gross, Litigating Whiteness: Trials of Racial Determination in the Nineteenth-Century South, 108 YALE L.J. 109, 137-41 (1998) (examining the use of physical characteristics to measure race in trials in the nineteenth-century South); see also Hudgins v. Wright, 1 Hening 134, 139 (Va. 1806) (observing that "[n]ature has stampt upon the African and his descendants two characteristic marks, besides the difference of complexion ... a flat nose and woolly head of hair").

22. When people think of racism, they usually think in terms of the harms inflicted upon Blacks without considering the benefits afforded Whites. Indeed, White is not commonly viewed as a racial identity. Rather, White has assumed a quality of invisibility. It is the dominant, unexamined, background norm. In recent years, however, scholars have begun to explore Whiteness as a racial identity and the privileges it carries. See, e.g., IAN F. HANEY LóPEZ, WHITE BY LAW: THE LEGAL CONSTRUCTION OF RACE 197-202 (1996) (discussing the reluctance of Whites to dismantle a racial category which has value to its possessors); Cheryl I. Harris, Whiteness as Property, 106 HARV. L. REV. 1709, 1726 (1993) (placing the privileges of Whiteness within the Madisonian definition of property); john a. powell, The "Racing" of American Society: Race Functioning as a Verb Before Signifying as a Noun, 15 LAW \& INEQ. J. 99, 120 (1997) (advocating an effort to understand and challenge Whiteness as a privileged category). The importance of Whiteness can be seen in recent cases and studies. For example, Professor Hacker recounts that in one study, White students were presented with a parable in which they were told that as a result of an organizational error, they had been born Black. In order to 


\section{the socioeconomic hierarchy. ${ }^{23}$ \\ Racial designations, however, are not made solely on the basis of skin color. Historically, other factors have been used to assign people to racial categories, including, among other things, ethnicity ${ }^{24}$ and bloodlines. ${ }^{25}$ For example, even if one is so light as to appear White, if}

rectify the problem, the students would be required to live the remainder of their lives as Black men or women in America, but the organization was willing to offer financial compensation for its mistake. Each student was asked how much financial compensation he/she required. Interestingly, the majority seemed to feel that it would not be out of place to ask for $\$ 50$ million, or approximately $\$ 1$ million for each year the student would have to live as Black. Based upon the study, Professor Hacker concluded that White persons were unwilling to become Black regardless of financial compensation. See ANDrew HaCKer, Two Nations: Black AND White, SePARATE, Hostile, UNEQUAL 31-32 (1992). He notes:

All white Americans realize that their skin comprises an inestimable asset. ... Its value persists not because a white appearance automatically brings success and status .... What it does ensure is that you will not be regarded as black, a security which is worth so much that no one who has it has ever given it away.

Id. at 60 .

23. Admittedly, some members of the Black community prize Blackness over Whiteness and may exclude individuals who are not "Black enough." See Leonard M. Baynes, Who is Black Enough for You? An Analysis of Northwestern University Law School's Struggle over Minority Faculty Hiring, 2 MICH. J. RACE \& L. 205, 226 (1997) (describing the exclusionary characteristics of the "American Black community"); Jim Chen, Unloving, 80 IOWA L. REV. 145, 156 (1994) (critiquing "racial fundamentalism"); john a. powell, The Colorblind Multiracial Dilemma: Racial Categories Reconsidered, 31 U.S.F. L. REV. 789, 802 (1997) (arguing that the acceptance of lighter-skinned Blacks in the Black community "has often been provisional and with qualifications"). The White community, however, maintains the norm that White is better. See powell, supra note 22, at 124 .

24. Under ethnicity theory, race is considered one factor in ethnic group formation. For a comprehensive discussion of indicators of ethnic identity, see DONALD L. HOROWITZ, ETHNIC GROUPS IN CONFLICT 41-54 (1985). For a critique of ethnicity theory, see López, supra note 15, at 20-24; see also St. Francis College v. Al-Khazraji, 481 U.S. 604, 611 (1987) (noting that encyclopedias in the nineteenth century "described race in terms of ethnic groups" as well as referring more broadly to "stock").

25. For example, for much of its history in the United States, the Black race has been defined by the one-drop rule. See F. JAMES DAVIS, WHO Is BLACK? ONE NATION'S DEFINITION 5 (1991). Under that rule, anyone with even a single drop of "Black blood" is Black. See id. At various points throughout U.S. history, many states, including Alabama, Arkansas, Florida, Georgia, Indiana, Kentucky, Louisiana, Maryland, Mississippi, Missouri, Nebraska, North Carolina, North Dakota, Oklahoma, Oregon, South Carolina, Tennessee, Texas, Utah, and Virginia, defined as Black anyone with a specified amount of Black blood. See LóPEZ, supra note 22 , at 118-19. Some states used the one-drop rule. See id. Others employed a fractional definition (e.g., one-eighth, one-sixteenth, and one-thirty-second rules). See id. Still other states used murkier standards like the "appreciable amount" test. Id. Commentators have argued that these rules are inherently racist because they perpetuate the view that Black blood taints a person for life. See Neil Gotanda, A Critique of "Our Constitution is Color Blind", 44 STAN. L. REv. 1, 2627 (1991) (noting that under these rules, Black ancestry is viewed as a contaminant overwhelming the purity of White ancestry). In this Article, I maintain that the problem is not necessarily the one-drop rule, but rather society's conception of "blackness." As long as Black continues to be associated with negative characteristics (e.g., laziness, immorality, lack of intelligence, ignorance, criminal proclivities, shiftlessness, lasciviousness), it will still be possible to maintain a 
one's immediate ancestors are known to be Black, then one might still be considered Negroid. ${ }^{26}$ In that situation, one's skin color does not determine one's race. Rather, ancestry acts as the racial designator. ${ }^{27}$

system of oppression based upon the notion that Black is somehow evil and bad. Without a onedrop rule, some people may no longer be categorized as Black, but the category and oppression based upon it will still exist.

26. The facts of Plessy v. Ferguson, 163 U.S. 537 (1896), illustrate this phenomenon. Recall that in Plessy, the Supreme Court upheld a Louisiana statutory provision requiring separate railway cars for Blacks and Whites. In the opinion, the Court noted the petitioner's assertion that the "mixture of colored blood was not discernable in [Plessy]." Id. at 541. In other words, Plessy appeared White. But, according to his ancestry, Plessy was seven-eighths Caucasian and one-eighth Black. Thus, notwithstanding his white skin, Plessy could constitutionally be deemed a member of the colored race by the laws of Louisiana. See id. at 552.

Jane Doe v. Louisiana, 479 So. 2d 369 (La. Ct. App. 1985), provides a more recent example. In 1977, when obtaining a copy of her birth certificate to process a passport application, Suzy Guillory Phipps was told by the Clerk of the New Orleans Division of Vital Records that her racial designation was "colored." Hearing this information for the first time at the age of 43, Phipps confessed to being somewhat surprised. "I was brought up white. I married white twice. It shocked me. I was sick for three days." Calvin Trillin, American Chronicles: Black or White, NEW YORKER, Apr. 14, 1986, at 62. Phipps was so sick that she and various other family members filed suit against the state of Louisiana, contending that their birth certificates erroneously designated their parents as "colored." The children wanted the State to change their parents' racial designation to "White." Thus, notwithstanding the fact that the plaintiffs appeared White and had led White lives, they thought it sufficiently important to clear up the historical record concerning the identity of their parents, lest the children be considered Black. Indeed, the dissent explicitly validated their fear by pointing out that in the society in which the plaintiffs grew up, racial designations were made according to ancestral designations. See Jane Doe, 479 So. 2d at 373 (noting "you are what your parents are" and "plaintiffs will continue to be regarded as members of the black race by some segments of our society no matter what they proclaim themselves to be"). In the end, the court denied the plaintiffs' request, finding that they had failed to prove that their parents' racial designations were incorrect. See id. at 372 . It turns out that the children's great-, great-, great-, great-grandmother was a Black slave. Thus, the Plaintiffs were Black under a Louisiana statute that defined as Black anyone with a traceable amount of Black ancestry. Both the Louisiana and U.S. Supreme Courts refused to hear the case on appeal. See also Ozawa v. U.S., 260 U.S. 178, 198 (1922) (rejecting a citizenship claim of a Japanese person on the ground that race is not a function solely of skin color).

27. Professor Gotanda separates the above argument into two rules: (1) the "Rule of recognition: Any person whose Black-African ancestry is visible is Black"; and (2) the "Rule of descent:... Any person with a known trace of African ancestry is Black, notwithstanding that person's visible appearance...." Gotanda, supra note 25 , at 24 . He notes that the two rules create an asymmetrical system. The White race includes only people who are totally White whereas the Black race includes everyone else with a known drop of Black blood. See id. Interestingly, the United States is one of the few countries to have adopted an approach where mixture between a dominant and a subordinate race results in the progeny being cast into the subordinate group. See Joel Williamson, New People: Miscegenation and Mulattoes in the UNITED STATES 2 (1980). In other countries where such mixtures have occurred, the progeny have either been absorbed into the dominant race or classified as a distinct intermediate group. See id. As I point out later, it is not clear to me that the latter resolution has produced better results in terms of racial equality than the system adopted in the United States. See infra Part II.B.3. 
Thus, racial categorization does not rest solely upon skin color. Multiple factors are and have been used to indicate race. One should not confuse, however, the indicator (e.g., skin color or ancestry) with the thing that it is indicating (e.g., race). Skin color is one device for assigning people to a racial category. Race is the social meaning attributed to that category. It is a set of beliefs or assumptions about individuals falling within a particular racial group. These beliefs may be wide-ranging, comprising assumptions about the group's intellect, physical attractiveness, work ethic, class, and morality, among other things. For example, if one were to see Oprah Winfrey and Rosie O'Donnell on the street, Ms. Winfrey's brown skin tone would likely cause the viewer to conclude that she is Black. However, her skin color would not be the determinant of her status. That is determined by her classification as Black and the accompanying societal views attached to that racial classification.

With colorism, skin color does not serve as an indicator of race. Rather, it is the social meaning afforded skin color itself that results in differential treatment. For example, envision a situation in which two individuals fall within the same race-one is milk chocolate brown and the other is dark chocolate brown. Despite the fact that both persons are members of the same race, one may receive superior treatment based upon her skin color. ${ }^{28}$ When encountering these two individuals, the viewer does not use skin color to assign them to a particular racial category. Rather, any difference in treatment results not from racial categorization per se, but from values associated with skin color itself. Because it is views about color that trigger the differential treatment in this circumstance, this form of discrimination is most accurately called colorism. Thus, with colorism, it is the social meaning afforded one's color that determines one's status. With racism, it is the social meaning afforded one's race that determines one's status.

People often confuse skin color and race because skin color is used to assign people to racial categories. Indeed, colors are commonly used to describe racial categories (i.e., Black is used to describe African-Americans and White is used to describe Caucasians). In ad-

28. The relevant cases involve dark-skinned persons who claim to have been denied a position that is then given to a light-skinned member of her race (or vice versa) with similar qualifications. See, e.g., Walker v. Internal Revenue Serv., 713 F. Supp. 403, 408 (N.D. Ga. 1989) (allowing a Title VII claim to go forward based on a light-skinned Black woman's allegation that her darker-skinned supervisor discriminated against her); Ali v. National Bank of Pak., 508 F. Supp. 611, 614 (S.D.N.Y. 1981) (holding that a light-skinned Pakistani bank worker failed to establish a prima facie case of employment discrimination based on her lighter skin color). 
dition, people are misled because of the positive correlation between the values associated with being a member of the White race and the values attributed to a lighter skin tone. That is to say, notwithstanding pride-saving and race-affirming statements like "Black is Beautiful"29 and "the blacker the berry the sweeter the juice," "White is right" more accurately capture contemporary understandings of both the racial and the color hierarchy in the United States. Thus, with both race and skin color discrimination, the lighter one's skin tone, the better one is likely to fare economically and socially. This parallelism often leads people to assume that racism and colorism are the same. ${ }^{31}$ As I have explained above, they are not.

It is important to note that colorism operates both intraracially and interracially. ${ }^{32}$ Intraracial colorism occurs when a member of one racial group makes a distinction based upon skin color between members of her own race. Thus, when elite Black social clubs denied membership to applicants who were too dark in the nineteenth and early twentieth centuries, they were practicing intraracial colorism. ${ }^{33}$ Interracial colorism occurs when a member of one racial group makes a distinction based upon skin color between members of another ra-

29. "Black is Beautiful" was a popular slogan used among Black Americans in the 1960s and 1970s to reflect and to encourage racial pride. The slogan is often associated with Malcolm X. See Peter Goldman, The DeAth And Life of Malcolm X 398 (1979) (arguing that the central goal of Malcolm's ministry was "to reveal to black people their own beauty and worth and competence to find their own way").

30. This phrase, which has been widely used in the Black community for at least a century, expresses a preference for darker-skinned mates. See PAul R. SPICKARD, MiXed Blood: INTERMARRIAGE AND ETHNIC IDENTITY IN TWENTIETH-CENTURY AMERICA 322 (1989).

31. To some extent, the tendency to conflate racism and colorism is excusable. In some cases, colorism may be a derivative of racism in the sense that differences in skin pigmentation draw meaning from society's views of race. That is, color has meaning in some instances because being light or dark is associated with being of, or closer to, a certain racial ideal-White. Colorism, however, may be informed by factors other than race (e.g., historical values associated with the colors white and black, etc.). See infra discussion at Part II.C for further discussion of the social psychology of black-white colorism. In addition, it is important to keep the two concepts analytically distinct in order to detect the operation of colorism. If one were to merely focus on racial categorization, then one might never see colorism at work. For example, assume that an employer hires Black women. If one merely focuses on the fact that Blacks are hired, then one might not see that some, let us assume lighter-skinned, Black women may be preferred over others due to their skin color.

32. Although the race of the discriminator may differ in these scenarios, the fundamental claim or act of discrimination is the same: the discriminator is distinguishing between individuals on the basis of skin tone. By intraracial color discrimination, I mean that the discriminator is a member of the same race as the victim. By interracial, I mean that the discriminator is of a different race than the two individuals who are being compared.

33. See SPICKARD, supra note 30, at 317 (noting that in some Black communities, "lighttoned people maintained their own clubs (such as Nashville's Blue Vein Society)"). 
cial group. For example, a White Hollywood producer might make casting choices between Whoopi Goldberg ${ }^{34}$ and Halle Berry ${ }^{35}$ on the basis of skin color. ${ }^{36}$ Colorism may also occur outside of this comparative framework. As I explain in Part III, people may use color simply as a trigger for difference when they cannot place a person within a specific racial category.

Notwithstanding the complex history of colorism, we have, for the most part, bluntly divided the world into White and Black and regarded all individuals within a particular category in a monolithic fashion as if they were subject to the same treatment. As noted above, however, the matter is not merely one of distinguishing between White and Black, for within these broad categories further distinctions have been and continue to be made based upon skin color. Simply put, not all colors (or tones) are equal, and many proceed upon the belief that, even within groups, "lighter is righter." In order to understand the nuanced ways in which discrimination operates and differentially impacts similarly but not identically situated people, we must examine and attempt to understand color. Such understanding begins with history.

\section{Color Distinctions Through THE LENS OF TIME}

The practice of race-mixing in the United States produced a population with skin tones of varying hues. Over time, society attached various meanings to these color differences, including assumptions about a person's race, socioeconomic class, intelligence, and

34. Whoopi Goldberg is a dark-skinned African-American actress and comedienne. She has starred in such blockbuster hits as SARAFINA (Hollywood Pictures 1992), SISTER ACT (Touchstone 1992), GHOST (Paramount Pictures 1990), ClARA's HEART (Warner Brothers 1988), and The Color PurPle (Warner Brothers 1985). See Patrick Spreng, ACME Whoopi! (visited Mar. 24, 2000) <http://www.acmewebpages.com/whoopi/index.html> (on file with the Duke Law Journal).

35. Halle Berry is the product of a White mother and a Black father. Her skin may be best described as light tan. Ms. Berry has starred or co-starred in a number of motion pictures including, among others, BulworTh (20th Century Fox 1998), EXECUTIVE DECISION (Warner Brothers 1996), LOSING IsAIAH (Paramount Pictures 1995), BOOMERANG (Paramount Pictures 1992), and JUNGLE FEVER (Universal Pictures 1991). She is also a model for Revlon Cosmetics. See Mr. Showbiz Celebrities: Halle Berry Biography (visited Mar. 24, 2000) $<\mathrm{http}: / / \mathrm{mrshowbiz.go.com/people/halleberry/content/bio.html>} \mathrm{(on} \mathrm{file} \mathrm{with} \mathrm{the} \mathrm{Duke} \mathrm{Law}$ Journal).

36. See RUSSELL ET AL., supra note 2, at 143-51 (noting that producers have historically shown a preference for lighter-skinned Black actresses for romantic lead roles and arguing that despite her commercial appeal, most directors would not consider Whoopi Goldberg suitable as a love interest). 
physical attractiveness. In order to understand the development of the color hierarchy in the United States and the meanings attributed to skin color today, a survey of this history is necessary. Section A briefly reviews colorism before the Civil War. Section B examines colorism within the Black and White communities since Reconstruction. Section C explores the social psychology of contemporary colorism. Because short historical summaries rarely reflect variations in practices and beliefs within large geographical areas over time, it is important to keep in mind that there were exceptions to the general trends outlined in Section A that are not detailed here. In addition, the contrast between practices of the Upper South and Lower South was not always sharp. For example, tolerance for miscegenation in South Carolina ebbed and flowed from the colonial era until the Civil War.

\section{A. Before the Civil War: 1607-1861}

Professor Joel Williamson has noted that "Whites and blacks had been mixing in Africa, Europe, and Asia eons before Columbus sailed the western ocean. ${ }^{, 37}$ Thus, the first explorers to set foot on North American soil were technically mixed-race individuals. Accordingly, "black was never totally black, and white was never entirely white.",38

This pattern of race-mixing continued with the European settlement of Jamestown in 1607 and the arrival of the first Africans shortly thereafter. ${ }^{39}$ At a time when there was a shortage of White women, ${ }^{40}$ it was not uncommon for White men to interact sexually with Black

\footnotetext{
37. WILliAMSON, supra note 27, at xiii; accord DAVIS, supra note 25, at 28-29.

38. WILlIAMSON, supra note 27 , at xiii.

39. See James Hugo Johnston, Race Relations in Virginia and Miscegenation IN THE SOUTH 1760-1860, at 165-66 (1970) (pointing out that "[t]he crossing of the two races commenced at the very out-start of the vile slave trade that brought [African slaves] thither; indeed in those days many a negress was landed upon our shores already impregnated by someone of the demoniac crew that brought her over") (quoting R. W. SHUFELDT, THE NEGRO, A MENACE TO AMERICAN CIVILIZATION 60 (1907); Williamson, supra note 27, at 6-7 (noting that "[ $\mathrm{t}]$ he first significant mixing of blacks and whites came in the 17 th and early 18 th centuries" in Virginia and Maryland).

40. Because America was a frontier society in the seventeenth century, there were "many more men than women, especially in the southern colonies." SPICKARD, supra note 30, at 236. "Among Africans, there were at least three men for every two women.... [A]mong Whites, men outnumbered women by as many as three or four to one." RUSSELL ET AL., supra note 2, at $11-12$.
} 
women. ${ }^{41}$ Whether miscegenation ${ }^{42}$ was objectionable to ruling-class Whites depended upon the characteristics of the participants. Because the status of children followed that of the mother, ${ }^{43}$ White planters would receive an economic advantage (by increasing their slave holdings) through miscegenation with Black slave women. ${ }^{44}$ Miscegenation among non-landed lower classes, however, caused landed elites to fear that Black slaves and poor indentured White servants might unite against them and threaten the existing socioeconomic order. ${ }^{45}$

41. See FRANKLIN \& Moss, supra note 14, at 139 (noting that miscegenation between Black men and White women accounted for a small percentage of racial mixing during the slave era); A. Leon Higginbotham, Jr. \& Barbara K. Kopytoff, Racial Purity and Interracial Sex in the Law of Colonial and Antebellum Virginia, 77 GEO. L.J. 1967, 1997 (1989) (noting that interracial sex involving White women posed a "direct assault on white racial purity"). Unions between Black men and White women were much less common for a variety of reasons, including the fact that there were "far too few White females in the colonies for White authorities to tolerate their being sexually active with Black men.” Russell ET AL., supra note 2, at 13. As a result, harsh penalties were imposed for such transgressions. See id. "In Maryland, for example, a White female servant who had sex with a Black male slave was subject to a lifetime of enslavement." Id. The Black men involved in these relationships risked even harsher penalties. "If caught, they could be whipped, castrated, or murdered for defiling 'the sanctity of White womanhood." Id. at 22-23. Indeed, some Black men were lynched simply for looking at a White female. See id. at 12, 23.

European colonists also seduced or raped Native American women. Because their numbers were small, little is known about the offspring of these unions. See id. at 10.

42. According to Webster's Dictionary, the term "miscegenation" means the "interbreeding of what are presumed to be distinct human races, esp. marriage or cohabitation between White and Nonwhite persons.” WEBSTER's II NEW RIVERSIDE UNIVERSITY DICTIONARY 757 (2d ed. 1988) [hereinafter WEBSTER's]. Black's Law Dictionary defines miscegenation as: "Mixture of races. Term formerly applied to marriage between persons of different races." BLACK's LAW DICTIONARY 999 (6th ed. 1990). The term "miscegenation" was first used in 1864 in an anonymous pamphlet entitled Miscegenation: The Theory of the Blending of the Race, responding to the Democratic Copperheads' accusation that Lincoln and the abolitionist Republicans were plotting "compulsory inter-marriage." The pamphlet, attributed to New York reporter David Croly, "coined the term 'miscegenation,' and it predicted approvingly the inevitable sexual mixing of the races at some future time." SPICKARD, supra note 30 , at 283 . As used in this Article, the term "miscegenation" includes both interracial sex and interracial marriage.

43. See infra note 53; see also Wilbert Moore, Slave Law and the Social Structure, $26 \mathrm{~J}$. NEGRO HIST. 171, 185-86 (1941) (noting that by the 18th century, all states had adopted the principle that a person's status as slave or free followed the status of the mother).

44. See Higginbotham \& Kopytoff, supra note 41, at 2006 (citing this as one of the two main effects of the rule of slave inheritance); see also RUSSELL ET AL., supra note 2, at 13-14 (noting that the Virginia statute, and others like it, tacitly encouraged slave owners to increase their slave holdings (and consequently their economic status) by raping their Black female slaves). To be sure, the extent to which this economic advantage actually shaped views and behaviors is subject to question because the presence of mixed offspring had the potential to create domestic problems for White planters.

45. Historians are divided over whether the ideology of racism was fully developed in the seventeenth century and, consequently, over the extent to which beliefs in the inferiority and inhumanity of Blacks affected views on miscegenation early in the colonial era. Indeed, early 
As early as 1662 , anti-miscegenation statutes began to appear. ${ }^{46}$ These statutory enactments, however, neither eliminated voluntary sexual relations between Whites and Blacks nor thwarted the sexual aggression of White slave owners towards their Black female slaves. ${ }^{47}$ As the offspring of these unions proliferated, colonists soon faced a pressing question: were these children Black (and therefore slaves) or White (and therefore presumptively free) $?^{48}$ The origin of colorism is inextricably linked to the way in which colonial legislatures responded to this question because one of the more distinguishing features of mulattoes, ${ }^{49}$ or mixed-race individuals, was skin tone. ${ }^{50}$

slavery efforts may have been driven in part by pragmatic concerns. It was simply easier to maintain the enslavement of Blacks because their skin tone made them readily identifiable. See FRANKLIN \& MOSS, supra note 14, at 32. Miscegenation complicated matters by muddying the line of demarcation between those who were enslaved and those who were free. As the ideology of racism evolved, miscegenation grew increasingly problematic because White-Black attraction was inconsistent with the underlying theory of White racial superiority. See generally JOHNSTON, supra note 39; Higginbotham \& Kopytoff, supra note 41.

46. See 2 Hening 170 (Va. 1662) (mandating that the mixed-race children of Black female slaves be enslaved). Maryland (1662), Massachusetts (1705), North Carolina (1715), Delaware (1721), and Pennsylvania (1725) adopted similar statutes in the latter part of the seventeenth century and in the early years of the eighteenth century. See JOHNSTON, supra note 39, at 166 (collecting those statutes). It is impossible to isolate the exact reason or reasons underlying the enactment of these statutes. See supra note 45. As Professor Horowitz notes, the statutory provisions may have resulted from "planters' desire to prevent conspiracies of servants and slaves, the inadmissibility of unions of Christians with heathens (as some of the legislative preambles suggest), or rivalries over scarce women." Donald L. Horowitz, Color Differentiation in the American Systems of Slavery, 3 J. INTERDISC. HIST. 509, 526 (1973) (internal citations omitted). Others have noted the significant increase in the Black population in certain colonies between the early and later part of the seventeenth century. For example, the Black population in Virginia in 1650 was approximately 300 persons, while the White population was approximately 15,000. In 1671, the number of Blacks was approximately 2,000 while approximately 38,000 were White. See WiLliamson, supra note 27, at 7. It is reasonable to conclude that when the number of Blacks was small, the need for legal regulation of interracial relations was minimal. As the numbers increased, miscegenation laws began to appear.

47. See JOHNSTON, supra note 39, at 167-68 (pointing to the growing number of mulattoes as proof of the continuance of sexual relations). In colonial Virginia, White men were not punished for the rape of Black women. See Higginbotham \& Kopytoff, supra note 41, at 2008-12.

48. Arguably, the child of a White and a Black parent had an equal claim to being classified as either White or Black, as both White and Black, or as neither Black nor White.

49. According to Webster's Dictionary, the term "mulatto" originated from the Spanish word "mulato," meaning "young mule." WeBsTER's, supra note 42, at 775. Webster's defines "mulatto" as: "1. One having one White and one Black parent. 2. One of mixed Black and White ancestry." Id. Black's Law Dictionary offers the following definition: "A person that is the offspring of a negress by a white man, or of a white woman by a negro. In a more general sense, a person of mixed Caucasian and negro blood, or Indian and negro blood." BLACK's LAW DiCTIONARY, supra note 42, at 1014. According to Naomi Zack, the Devil's Dictionary, compiled between 1881 and 1906, defined mulatto as: "A child of two races, ashamed of both." NAOMI ZACK, RACE AND MIXED RACE 112 (1993).

50. Although a person's mixed racial identity could in some cases be deduced from knowledge of the parents' races, this information was not always available, given that accurate records 
1. The Upper South. In the Upper South (the area reaching south from Pennsylvania into parts of North Carolina) the initial interracial unions primarily involved White male indentured servants and Black slave women. ${ }^{51}$ As a result, colonial legislators in this region took the harshest stance against miscegenation and mixed-race individuals. ${ }^{52}$ To deter miscegenation, these legislators proclaimed that the children of Black slave women would be slaves notwithstanding the race of their fathers (and their lighter skin tones). ${ }^{53}$ Although settling the status of a large number of mulattoes, ${ }^{54}$ this legislation did not completely resolve the matter; mulatto children born of free White women or free Black women remained free.

In response, legislatures in the Upper South undertook additional measures to resolve the status of mulatto children of White women and to deter interracial marriage. For example, in 1691, the

were not kept and given the pervasive division of slave families throughout the period of slavery. See Johnston, supra note 39, at 191-216 (describing the problem of racial identity generally). Thus, skin color played a critical role in anti-miscegenation efforts and in determining who was Black. A child born with too little or too much color indicated that race-mixing had occurred. See Christine B. Hickman, The Devil and the One Drop Rule: Racial Categories, African Americans, and the U.S. Census, 95 MICH. L. REV. 1161, 1228-30 (1997) (discussing the difficulty of "human title searches" and the ways in which "scientific experts" were called upon in trials to divine through visual inspection the quantum of Black blood a person possessed).

51. See Williamson, supra note 27, at 7; see also Horowitz, supra note 46, at 526-27 (noting that most early interracial unions involved indentured servants and slaves and pointing out that the low status of their white ancestors prevented mixed-race offspring from receiving special treatment). Some of these servants had voluntarily migrated to the British colonies under indenture. Others were sentenced by British courts to servitude in the colonies. Regardless of how they came to be here, these servants were part of the lower class: they performed menial work and worked closely with both enslaved and free Blacks. See WiLliamson, supra note 27, at 7 .

52. See DAVIS, supra note 25, at 33-34 (noting that "[f]rom the beginning, the one-drop rule for mulattoes seemed natural to the elites of the upper South, since the whites involved in the racial mixing were an underclass of indentured servants").

53. For example, Virginia's statute stated:

Whereas some doubts have arisen whether children got by any Englishman upon a negro woman should be slave or free, Be it therefore enacted and declared by this present grand assembly, that all children borne in this country shall be held bond or free only according to the condition of the mother.

2 Hening 170 (Va. 1662). The act represented a significant departure from the traditional English rule "that the child followed the status of its father." WILLIAMSON, supra note 27, at 8; accord RUSSELl ET AL., supra note 2, at 13. See also supra note 45 and accompanying text (discussing the economic benefits White planters received as a consequence of raping their slaves).

54. See Williamson, supra note 27, at 8 (estimating that the 1662 legislation resolved the status of perhaps more than half of the mulattoes in Virginia). 
Virginia Assembly ${ }^{55}$ declared that any English woman who gave birth to "a bastard child by any Negro or mulatto" would be heavily fined or subject to five years of servitude and that the child would be bound into servitude until it reached age thirty. ${ }^{56}$ On the subject of interracial marriage, Virginia threatened to banish from the colony any White person who married a Negro or mulatto. ${ }^{57}$ To some extent, this provision deterred miscegenation between free Black women and White men.

These legislative efforts, designed to prevent future miscegenation, did not address the status of free mulattoes already in the population. For the most part, these mulattoes were poor and were regarded unfavorably by the ruling elite. ${ }^{58}$ Not surprisingly, they came to be classed with and to occupy the same status as Blacks. ${ }^{59}$ Again, the situation in Virginia is illustrative. In a 1705 statute, Virginia prohibited Blacks, Indians, and mulattoes from holding office and from serving as witnesses in legal proceedings. ${ }^{60}$ Shortly thereafter, in 1723, Virginia ordered that free mulattoes could no longer vote ${ }^{61}$ and could only possess firearms under special, highly restrictive circumstances. ${ }^{62}$

55. Many colonies followed Virginia's legislature. See supra note 46. For a more detailed discussion of interracial sex and marriage in colonial Virginia, see generally Higginbotham \& Kopytoff, supra note 41 (documenting the laws of racial purity and interracial sex in pre-Civil War Virginia).

56. 3 Hening 87 (Va. 1823).

57. See id. In 1705, the penalty was changed to six months in jail. See id. at 453-54. In 1664, Maryland had enacted an even harsher law to discourage marriages between Black slaves and White women. The law provided that "such women must serve the masters of their husbands during the lifetime of the husband," and that the children of these unions would be slaves. WiLliamson, supra note 27, at 10. In 1715, the Maryland Assembly prohibited ministers and magistrates from performing marriages between Whites and Blacks. See id. at 11. Pennsylvania enacted similar laws in the early 1700s. See id.

58. See Williamson, supra note 27, at 9.

59. See id. at 9-13.

60. See 3 Hening 250 (Va. 1823). In that Act, Virginia defined a mulatto as "the child of an Indian and the child, grand child, or great grand child of a Negro." Id. at 252. Interestingly, this statute prohibited all former convicts (White and Black) from holding office. See id. at 250-51. By treating law-abiding free Blacks the same as White criminals, the statute affirmed the denigrated position of Blacks.

61. See 4 Hening 133-34 (Va. 1820) ("No free negro [or] mulatto... whatsoever, shall hereafter have any vote at the election of burgesses, or any other election whatsoever."). Before 1823 , there is some evidence that free Black males who owned land could vote. See 1 Hening 403 (Va. 1823) (repealing portion of a previous act that "excludes freemen from votes"); see also John H. Russell, The Free Negro in Virginia, 31 Johns HopkINS UNIV. STUD. 1913, at 119 ("[P]ossession of almost any property entitled a [black] man to voting privileges.").

62. See 4 Hening 131 (Va. 1820). In short, like free Blacks, free mulattoes "could keep one gun, powder and shot" if they were housekeepers or enlisted in the militia, or if they lived on a frontier and obtained a license. $I d$. 
Thus, by the mid-eighteenth century, mulattoes were "firmly classed with Negroes and in effect lumped on that side of the race bar."

As the Revolutionary War approached, the number of free Blacks and mulattoes in the Upper South increased, ${ }^{64}$ and authorities became increasingly pressed to draw a sharp line between the privileges of White citizens and those of free Blacks. ${ }^{65}$ Inevitably, colonial legislators were called upon to determine with more clarity who was Black. ${ }^{66}$ Acting in 1785 , Virginia defined a Negro as a person with a Black parent or grandparent. ${ }^{67}$ Over time, this definition was broadened to include persons with less than one-fourth Black blood. ${ }^{68}$ Ultimately, the one-drop rule was born. Under that rule, any person with even a drop of Black blood would have the same legal status as a pure African. ${ }^{69}$ As one scholar notes, "no matter how White looking or White acting someone of mixed ancestry [was] or how little Blackness [was] in a person's genetic makeup, that person [was] considered Black." ${ }^{, 70}$ In effect, the one-drop rule maintained the status quo of White privilege by casting mulattoes in the same role of social outcast as unmixed Blacks. ${ }^{71}$

63. WILlIAMSON, supra note 27, at 13; see also Hickman, supra note 50, at 1178-79 (pointing out that beginning in the mid-seventeenth century, colonial legislatures added the phrase "and mulattoes" to laws directed at Black slaves in order "to ensure that mulattoes were subject to the same restrictions as Negroes").

64. Slave owners in the Upper South emancipated a number of slaves for ideological and economic reasons during the Revolutionary Era. See WILLIAMSON, supra note 27, at 13.

65. See id. at 13 .

66. See id.

67. See 8 Hening 1823 (Va. 1787). As a result of this enactment, some individuals who were classified as mulatto in 1705 began to be classified as Black. Other legislatures followed Virginia's example. See supra note 46; see also IRA BERLIN, SLAVES WITHOUT MASTERS 99 (1974) (noting that many states in the lower South followed Virginia's example).

68. Apparently, many White Virginians were dissatisfied with labeling anyone with less than one-fourth Black blood as White. This "rather generous fraction classed as white . . . some people who were significantly black, visibly black, and known to be black." WILLIAMSON, supra note 27 , at 13 . In short, these individuals were socially Black, but legally White. As such, they were entitled to the privileges of Whites and to greater protection under the law. See id.

69. The rule is also known as the "one Black ancestor rule," the "traceable amount rule," and the "hypo-descent rule, meaning that racially mixed persons are assigned the status of the subordinate group." DAVIS, supra note 25, at 4-6. Some scholars argue that the rule originated from "racist concern about contamination of the White gene pool." RUSSELL ET AL., supra note 2 , at 14 .

70. RUSSELL ET AL., supra note 2, at 14.

71. See Williamson, supra note 27, at 9-10. By making the mulatto category indistinct from Black, Whites created the "fiction that any trace of Black made a person Black," and hence they could "assure themselves of their separateness and 'purity." Kenneth E. Payson, Check One Box: Reconsidering Directive No. 15 and the Classification of Mixed-Race People, 84 CAL. L. REV. 1233, 1247-48 (1996). 
2. The Lower South. The Lower South (the region extending from parts of North Carolina southward to the Gulf of Mexico) exhibited greater tolerance for racial mixing. ${ }^{72}$ For example, in South Carolina, vast plantations with large numbers of Black slaves resulted in White slave owners and overseers having constant sexual access to Black slave women. As a result, racial mixing among White men and Black slave women was frequent. ${ }^{73}$ Tolerance for racial mixing was equally strong in Louisiana, especially in New Orleans, where mixing between Blacks and Whites reached its highest levels due to a surplus of White men and mulatto women. ${ }^{74}$ As one scholar has noted, "[s]o common was mixing among the elites of both races that it came to be institutionalized in "quadroon balls.", 75 These balls were social events at which wealthy White men courted prospective mulatto mistresses. ${ }^{76}$

Consistent with its more lenient stance on miscegenation, the Lower South took a more generous view of free mulattoes. Unlike the Upper South, the Lower South afforded free mulattoes a status

72. See BERLIN, supra note 67, at 196 ("Not only was it easier for light skinned freemen to pass for white in the Lower South, but once they were accepted as 'white,' few questions were asked."); WILLIAMSON, supra note 27, at 15 (asserting that free mulattoes were "treated by influential whites [in the Lower South] as a third class").

73. See WiLliamson, supra note 27 , at 15 . Over time, as more White settlers brought their wives and families to the colony, pressure for interracial sex decreased, and interracial liaisons came under attack. By 1717, South Carolina had begun to implement measures to curb racial mixing. In that year, the South Carolina Assembly ruled that:

"[A]ny white woman, whether free or a servant, that shall suffer herself to be got with child by a negro or other slave or free negro ... shall become a servant for ... seven years." The children of such unions were to be bound for twenty-one years if male and eighteen years if female. Further, white men who impregnated Negro women were to suffer the same punishment.

Peter H. Wood, Black Majority: Negroes in Colonial South Carolina From 1670 Through the StONo Rebellion 99 (1974) (quoting 3 South CAROLINA STATUTES AT LARGE 20 (1838)). Notwithstanding this shift in attitude, South Carolina was notably tolerant of free mulattoes and interracial unions between White men and Black women until the 1850s. Indeed, "throughout the era of slavery racial intermarriage was never prohibited in South Carolina, nor was it punished by law." WILLIAMSON, supra note 27, at 17 (emphasis added).

74. John Blassingame has noted that "[t]he most unique feature of race relations in antebellum New Orleans was the pervasiveness of miscegenation." JOHN W. BLASSINGAME, BLACK NEW ORLEANS 1860-1880, at 17 (1973). For a more detailed examination of mulattoes in Louisiana, see generally VIRginia R. DOMínguez, White BY DEFINITION: Social CLASSIFICATION IN CREOLE LOUISIANA (1986).

75. WILLIAMSON, supra note 27 , at 23.

76. After making a selection, the man would propose an arrangement which usually consisted of an agreement to keep the woman in a certain style (somewhere between a wife and a concubine) and to provide for any resulting children. Although these arrangements sometimes became permanent, they were usually temporary and often lasted for only a few months or years. See id. 
superior to that of Blacks. ${ }^{77}$ Although mulattoes in the Lower South were not as numerous as those in the Upper South (and not as many were free), those who were free tended to dominate the free Black community in both numbers and influence. ${ }^{78}$ The lightest of the lightskinned lived almost as well as their White neighbors. In Louisiana, free mulattoes were particularly prosperous. In fact, some were wealthy slave-owning planters ${ }^{79}$ whose children were educated abroad. ${ }^{80}$

Several factors may have contributed to the Lower South's more lenient regard for mulattoes. Free mulattoes in the Lower South were often the children of wealthy White men as opposed to the White underclass. ${ }^{81}$ Some of these men freed their mixed-race offspring and helped them to develop trades and businesses. ${ }^{82}$ Thus, even though their numbers were smaller than in the Upper South, free mulattoes in the Lower South benefited from the socioeconomic status of their White fathers. Even among the enslaved, slave owners sometimes displayed a preference for mulattoes by assigning them to less onerous indoor positions as domestics or artisans.

The influential presence of White immigrants from the British Islands of the West Indies also contributed to the elevated stature of free mulattoes in the Lower South. For example, some of the richest

77. See id. at $14-23$.

78. In $1850,200,000$ mulattoes lived in the Upper South, whereas only 90,000 mulattoes lived in the Lower South. While over a third of mulattoes were free in the Upper South in 1850, only 1 in 10 mulattoes was free in the Lower South. See SPICKARD, supra note 30, at 247.

79. See Williamson, supra note 27, at 20 ("In 1830 eight of the eleven Negroes in America who owned more than fifty slaves were Louisianans. The census of 1850 counted 242 free persons of color in Louisiana as planters, some of whom were very rich.").

80. Professor Williamson recounts the history of one such family, the Metoyer clan of the Cane River Creoles. Briefly, Marie Thérèze Coincoin, an African slave, became the mistress of Claude Metoyer, a wealthy White land owner. In 1778, after she had produced seven children by Metoyer, Metoyer purchased and freed Coincoin. By 1830, Marie and Claude's offspring owned 237 slaves, and their wealth exceeded that of many of their White peers. The Metoyers retained lawyers, worshiped with Whites in churches built by the Metoyers, owned stately homes, and were educated in Europe. Interestingly, although the early Metoyers were half-African and halfEuropean, they refused to identify as either Black or White. Rather, they maintained their separate identity and eventually married almost exclusively within the clan. See id. at 21-22. Williamson's summary relies heavily on GARY B. Mills, THE Forgotten PEOPLE: CANE RIVER's CREOLES OF COLOR (1977).

81. See Williamson, supra note 27 , at 14 ; see also Horowitz, supra note 46 , at 527-30 (pointing to a similar phenomenon in the British West Indies and in Latin American slave societies).

82. See Williamson, supra note 27 , at 15 .

83. See Bart Landry, The New Black Middle Class 24 (1987); see also Spickard, supra note 30 , at 248 (noting that mulattoes occupied special places on some plantations). 
and most influential settlers in South Carolina came from the most powerful families in Barbados. ${ }^{84}$ By the time Charles Town was settled in 1670, the superiority of mulattoes to Blacks was well established in Barbados, and this hierarchy was imported into South Carolina. ${ }^{85}$ A similar phenomenon occurred in lower Louisiana, where French immigrants and settlers from the island of Santo Domingo heavily influenced colonial society. ${ }^{86}$

Thus, instead of grouping mulattoes into the undifferentiated category of Black, the Lower South treated mulattoes as a third category, an intermediate class between Blacks and Whites. ${ }^{87}$ Pragmatic reasons drove southern Whites to maintain this buffer class. The need for large-scale slave labor on massive sugar and rice plantations meant that the number of Blacks greatly outnumbered the number of Whites in many areas of the Lower South. ${ }^{88}$ Fearful Whites looked to mulattoes as a mediating influence to help control Black slaves. The report of a legislative commission appointed to investigate a planned slave insurrection in 1822 captures the thinking of southern Whites. The commission noted:

[F]ree mulattoes are "a barrier between our own color and that of the black - and, in cases of insurrection, are more likely to enlist themselves under the banners of the whites.... Most of them are industrious, sober, hardworking mechanics, who have large families and considerable property; and so far as we are acquainted with

84. See Williamson, supra note 27, at 16 . Indeed, between 1670 and 1730 , six governors of South Carolina were Barbadian. See id.

85. See id. For comparative analysis of the formation of a distinct mulatto class in the British West Indies and the absence of such a class in colonial North America see generally Horowitz, supra note 46 (demonstrating the "insufficiency" of economic arguments and drawing attention to the influence of extensive planter concubinage and security needs in elevating the status of mulattoes in the British West Indies and Latin America).

86. Until 1803, Louisiana was possessed by Spain and France. The racial system developed in the Caribbean thus carried over to the mainland. See WiLLIAMSON, supra note 27, at 20.

87. Three racial classifications were acknowledged in Louisiana and Santo Domingo: White, Black (mostly slaves), and free colored (mostly mulatto). See Laura Foner, The Free People of Color in Louisiana and St. Domingo: A Comparative Portrait of Two Three-Caste Slave Societies, 3 J. Soc. HIST. 406, 430 (1970) (concluding that the three-caste system created an antagonistic relationship between slaves and free people of color because, though a separate category, the latter "mirrored the values of white society ... and aspired to full participation in white society rather than its destruction or transformation"); see also WILLIAMSON, supra note 27, at 15 (discussing tensions among the three-class society of the lower South).

88. Indeed, by 1708 , South Carolina probably had a Black majority due to the importation of slaves to work its rice plantations. The ratio of Blacks to Whites in the low country of South Carolina at the time of the American Revolution is estimated at three-to-one. See WILLIAMSON, supra note 27 , at 16 . 
their temper, and dispositions of their feelings, abhor the idea of association with the blacks in any enterprise that may have for its object the revolution of their condition. It must be recollected also, that the greater part of them own slaves, and are, therefore so far interested in this species of property as to keep them on the watch, and induce them to disclose any plans that may be injurious to our peace - experience justifies this conclusion. ${ }^{, 89}$

As a consequence of the above factors, authorities in South Carolina did not adopt the one-drop rule, which would have destroyed the three-tier hierarchy. Instead of determining status by blood, South Carolina authorities elevated free mulattoes who maintained a good reputation in the community and gave them access to White privileges. Mulattoes who were "proper acting," a quality determined by their wealth and education, could even apply for legal standing as "White." A0 Authorities in Louisiana also rejected the onedrop rule and instead made fine distinctions on the basis of skin tone and genealogy. For example, in some places, persons who were onesixty-fourth Black were called "sang-meles"; persons three-fourths Black were called "sambos"; and persons seven-eighths Black were referred to as "mangos." "Such fractional divisions were impossible to determine with precision absent knowledge of a person's ancestry; therefore, these distinctions were often made on the basis of skin color.

Thus, by the mid-nineteenth century, two trends were apparent. In the North and in the Upper South, mixed-race persons shared the same status as Blacks under the one-drop rule. In the Lower South, distinctions within the Black population based upon mixed-racial heritage and skin color were made routinely. Skin color differences were indicators of relative status. In addition, the mulatto hypothesis- the theory that light-skinned Blacks were intellectually superior because of their White blood-was well established within the White

89. Id. at 18 (quoting A South CARolinian, A Refutation of the CAlumnies Circulated Against the SOUTHERn AND WESTERn STATES, RESPECTING THE EXISTENCE of Slavery Among Them, to Which is AdDed a Minute and PARTicular ACCOUNT of THE ACTUAL CONDITION OF THE NEGRo POPULATION 84-85 (1882)); see also Horowitz, supra note 46, at 530-38 (noting a similar dynamic at work in the British West Indies).

90. Those with light-enough skin and European features commonly circumvented the law by simply passing as White. For discussion of the practice of "passing," see infra note 137 and accompanying text.

91. Williamson, supra note 27, at 24. "Sang-mele" is French for "half-caste." Collins RobERT FRENCH-ENGLISH ENGLISH-FRENCH DiCTIONARY 605 (7th ed. 1984). 
community. ${ }^{92}$ Mulatto slaves brought the highest prices on the slave market and were awarded some of the most coveted indoor assignments on plantations, while the more arduous field work was typically left to darker-skinned slaves. ${ }^{93}$

The preferential treatment received by some mulattoes (and the fact that some mulattoes owned slaves in the Lower South) inevitably infected relations between Blacks and mulattoes. As light-skinned slaves began to affect the ways of upper-class White families and to flaunt their higher social and educational achievements, discord developed within slave communities. ${ }^{94}$ Tensions escalated within communities of free Blacks as well due to an increase in the number of free Blacks in the post-Revolutionary War era. ${ }^{95}$ Fearing that Whites would associate them with the poorer, darker-skinned newly-freed slaves, some mulattoes in the Lower South began to discriminate actively against those who were darker than themselves and to socialize exclusively with other mulattoes.

As the nation moved towards civil war, southern Whites found it increasingly difficult to justify slavery once the color line had become blurred by a significant mulatto population. Not surprisingly, tolerance of miscegenation and the preferential treatment of mulattoes declined, as did support for the three-tier system of racial classification. ${ }^{96}$ Fueled by a need to defend slavery, the movement for persons to be identified as either White or Black gained in strength, and the Lower South gradually became a two-class society racially divided by the one-drop rule. By the start of the Civil War, voluntary sexual rela-

92. See RUSSELl ET AL., supra note 2, at 126-27.

93. See Williamson, supra note 27, at 17-18. Of course, life for all mulattoes was not easy. Free mulattoes were not afforded the same advantages as White citizens. See Higginbotham \& Kopytoff, supra note 41, at 1976-81. Moreover, the majority of mulattoes were enslaved. See supra note 78 . For these individuals, life was fraught with danger and peril. Mulatto women were particularly vulnerable to sexual exploitation by their predatory owners. Indeed, women who were one-quarter Black or one-eighth Black were in particularly high demand on the slave market. In addition, White-looking mulatto children were subject to abuse by the wives of slave owners in retaliation for their husband's sins. See RUSSELL ET AL., supra note 2, at 18-21; see also SPICKARD, supra note 30, at 245 (noting that White wives sometimes gave mulatto slaves extra work, punished them harshly and without provocation, and even demanded that they be sold).

94. See RUSSELL ET AL., supra note 2, at 18.

95. Many Black slaves escaped during the confusion of war, left to fight with the British, or were freed by exuberant slave owners enjoying the thrill of victory. See NATHAN IRVIN Huggins, Black Odyssey: THE Afro-American Ordeal in SlaVery 187-88 (1977).

96. See Williamson, supra note 27 , at 73-75. 
tions between Whites and Blacks were less common in the South. ${ }^{97}$ As Whites began to reject mulattoes, mulattoes, in turn, began to form alliances with Blacks. ${ }^{98}$

\section{B. After the Civil War: $1865-2000$}

Although sexual activity between the races declined in the wake of the Civil War, post-bellum anti-miscegenation efforts could not undo the results of more than two centuries of race-mixing. Skin color variations continued to expand within the Black population as mulattoes and Blacks interacted sexually. More importantly, the meanings ascribed to these color differences in the pre-Civil War era continued to play out within the Black community in the post-bellum period.

1. Colorism Within the White Community. By the latter part of the nineteenth century, ideas about biologically determined racial superiority were fully developed. ${ }^{99}$ Concerns that racial mixing would lower the biological quality of the White race fueled efforts to keep the races apart. ${ }^{100}$ By 1883 , the era of Jim Crow racism had begun, ${ }^{101}$ bringing laws that not only prohibited interracial marriage, but also mandated separate seating for Blacks and Whites in "trains, buses, theaters, libraries, and stores, and required separate schools, rest rooms, drinking fountains, parks, swimming pools, and other public

97. After 1850, miscegenation between Whites and Blacks virtually disappeared. See Payson, supra note 71, at 1247 (citing WILLIAMSON, supra note 27, at 33, 89). Even after the Civil War, when there was a shortage of White men, few White women turned to Black men as lovers or husbands. See DAVIS, supra note 25, at 49; Payson, supra note 71, at 1247 (noting that "[w]ith emancipation, anti-miscegenation sentiments reached a feverish pitch, leaving both Blacks and Whites disinclined to cross the color line") (citing WILLIAMSON, supra note 27, at 90). Moreover, "[v]igilante groups like the KKK had risen up, determined to keep the races apart." ZACK, supra note 49, at 125-26.

98. See DAVIS, supra note 25, at 43.

99. See John S. HALler, JR., OUtCASTS From EVOlution: SCIENTIFIC ATtitudes of RACIAL INFERIORITY 1859-1900 passim (1971); SPICKARD, supra note 30, at 283-90; WILLIAMSON, supra note 27, at 91-100.

100. See SPICKARD, supra note 30, at 283-90; see also Paul A. Lombardo, Miscegenation, Eugenics, and Racism: Historical Footnotes to Loving v. Virginia, 21 U.C. DAVIS L. REV. 421, 425-31 (1988) (probing the connection between eugenics and Virginia's anti-miscegenation law).

101. See DAVIS, supra note 25, at 52-54. During the period of Reconstruction (1865 to approximately 1877), the states ratified the Thirteenth, Fourteenth, and Fifteenth Amendments to the U.S. Constitution, and Congress passed a series of statutes designed to protect the civil rights of former slaves. In addition, Black Americans were elected to various governmental positions. See id. at 42-44. This period of improved status, however, was short-lived. 
facilities." ${ }^{102}$ This system of racial segregation was so prevalent that more than half of the states maintained anti-miscegenation statutes on their books as late as $1955 .^{103}$

Notwithstanding these statutes, miscegenation continued and the mixed-race population grew ${ }^{104}$ (although not as rapidly as in the preWar period). In response, states turned to racial classifications in an effort to restore the sharp line between White and non-White (a necessary measure in order to enforce Jim Crow laws). Legislation in Virginia illustrates the efforts of state legislatures to ensure that mixed-race individuals were legally defined as Black. Virginia created four racial classifications: White, Indian, Negro, and mulatto. From 1785 until at least 1910, mulatto was defined as a person with at least "one-fourth part or more of negro blood." that one-fourth was too generous a percentage, and in 1910, the Virginia legislature broadened the definition of "a colored person" to include any person who possessed at least one-sixteenth Black blood. ${ }^{106}$ Subsequently, in 1924, as paranoia about Whites being contaminated with Black blood grew, the Virginia legislature determined that a "white person" was a person with "no trace whatsoever" of Black blood. ${ }^{107}$ Similarly, in 1930, the legislature defined "colored" as "every

102. Id. at 52. The Supreme Court affirmed the constitutionality of this "separate but equal" approach to race relations in Plessy v. Ferguson, 163 U.S. 537 (1896). In Plessy, the Court upheld the constitutionality of a Louisiana statutory provision requiring separate railway cars for Blacks and Whites. See id. at 542-52. It was not until Brown v. Board of Education, 347 U.S. 483 (1954), that the separate but equal principle was overruled and statutory Jim Crowism was brought to a formal, if not de facto, end. In Brown, the Supreme Court held that racially segregated educational facilities were inherently unequal and therefore unconstitutional. See id. at 495.

103. Before the Supreme Court held Virginia's anti-miscegenation statute unconstitutional in Loving v. Virginia, 388 U.S. 1 (1967), many state courts viewed interracial marriage and biracial children as aberrations of the natural order. For example, in Naim v. Naim, 87 S.E.2d 749 (Va. 1955), the Supreme Court of Appeals of Virginia noted that miscegenation statutes "preserve the racial integrity of [a state's] citizens, ... regulate the marriage relation so that it shall not have a mongrel breed of citizens and prevent the obliteration of racial pride [that would] permit the corruption of blood [and] weaken or destroy the quality of its citizenship." Id. at 756. Likewise, in Berea College v. Commonwealth, 94 S.W. 623 (Ky. 1906), Kentucky's highest court expressed similar fears regarding racial mixing, noting " $[\mathrm{t}]$ he separation of the human family into races ... is as certain as anything in nature.... [R] ace prejudice [is] nature's guard to prevent amalgamation of the races ... and preserve[] the purity of blood." Id. at 626 .

104. See Bijan Gilanshah, Multiracial Minorities: Erasing the Color Line, 12 LAW \& INEQ. J. 183, 193-96 (1993).

105. 12 Hen. 1969 (Va. 1785).

106. 1910 Va. Acts ch. 357.

107. 1924 Va. Acts ch. 371. 
person in whom there is ascertainable any negro blood." ${ }^{, 108}$ Hence, the legislature codified the one-drop rule.

Although most Whites were content to operate under the onedrop rule, there is evidence to suggest that, when forced to deal with Blacks, Whites preferred Blacks with lighter skin tones. ${ }^{109}$ This preference was reflected in late nineteenth- and early twentieth-century literature. In that literature, color was critical to the characterization of Blacks, especially Black women. In a review of this material, Kathy Russell, Midge Wilson, and Ronald Hall note that "[w]hen portrayed as the romantic interest of either a Black or White man, the Black heroine was typically light-skinned, beautiful, and passive." heroines usually met with a tragic demise, earning such characters the name "tragic mulattas." Colorism was also apparent in employment practices. From Reconstruction to well into the twentieth century, de-

108. 1930 Va. Acts ch. 85. Importantly, although these statutes were couched in terms of blood, a distinguishing factor was skin color. As Judge Higginbotham and Ms. Kopytoff note:

For most mixed-race children, there were no formal genealogies, no marriage records, no legal marriages. It would have been difficult to prove that one was one-sixteenth rather than one-eighth Negro, or one-eighth rather than one-fourth, and for the most part, no one seemed to try. People did not base their legal claims on the exact proportion of white and non-white ancestry; when people claimed to be white, the matter was generally settled by appeal to their appearance.

Higginbotham \& Kopytoff, supra note 41, at 1983-84; see also id. at $1983-89$ (discussing the importance of phenotype in racial classifications); supra note 50 (explaining the use of "scientific experts" to discern an individual's racial composition).

109. Unfortunately, evidence of interracial colorism within the White community is not as well-documented as intraracial colorism within the Black community. The lack of extensive documentation, however, should not be interpreted to mean that interracial colorism is nonexistent or is not pervasive. Indeed, it would be illogical to conclude that Whites are immune from classification schemes that they initially developed and perpetuated for their own benefit.

110. Russell ET AL., supra note 2, at 135. Literary critic Sterling Brown argues that White stereotypes of mulattoes rested on racist assumptions. He notes that "the mulatto is a victim of a divided inheritance; from his white blood come his intellectual strivings, his unwillingness to be a slave; from his Negro blood come his baser emotional urges, his indolence, his savagery." Sterling A. Brown, Negro Character as Seen by White Authors, 2 J. OF NEgRo Educ. 179, 19495 (1933). For additional analysis of Black images in White literature during the nineteenth and early twentieth centuries, see RUSSELL ET AL., supra note 2, at 135-37.

111. RUSSELL ET AL., supra note 2, at 135-37. Russell notes that two theories are offered often by literary critics to explain the popularity of the tragic mulatta character. One theory posits that this genre afforded White females, the primary readers of romantic fiction, a means of acknowledging the history of plantation rape. The mulatta heroines, however, "had to die tragically lest the stories appear to sanction miscegenation." Id. at 136. A second theory holds that "only racially mixed Blacks were thought worthy of White readers' attention." Id. at 136. Unmixed Blacks were regarded as less complex and less interesting. See id. 
sired positions regularly went to lighter-skinned Blacks over equally qualified darker-skinned Blacks. ${ }^{112}$

Many of these trends continue today. As contact between the races has increased (especially in the aftermath of the civil rights movement), Whites still seem to prefer and to find less threatening persons who look more like themselves. ${ }^{113}$ These preferred individuals tend to be lighter-skinned and economically better-off. ${ }^{114}$ Black women who play romantic leads in major Hollywood films tend to have lighter skin and longer hair. ${ }^{115}$ Lighter-skinned women with European features predominate among successful Black contestants in beauty pageants and in music videos. ${ }^{116}$ They are also more likely than darker Blacks to be selected to endorse mainstream commercial products. ${ }^{117}$ In other employment settings, sociologists have found that even when researchers control for socioeconomic background, lighter-skinned Blacks fare better educationally and occupationally than their darker peers. ${ }^{118}$

Recent demographic changes highlight the continuing significance of skin color to the White community. With the rapid growth in the number of people of color in some parts of the United States, the need for a buffer class, or a group capable of bridging the gap between the "White elite" and the "untamed darker masses" may be

112. See id. at 127 . While good jobs were limited for Blacks, "highly educated mulattoes often worked as porters, waiters, domestic servants, gardeners, and drivers." Id. A number of mulattoes also worked as professionals in the 1930s. See id. (citing Caroline B. DAY, 10 A STUdy Of SOME NegRo-White FAMILIES IN THE UNITED STATES 114-15 (1932), cited in OtTo Klineberg, CHARACTERISTICS OF THE AMERICAN Negro 346 (1944)).

113. See RUSSELl ET AL., supra note 2, at 17-18, 127-28, 150-62 (examining this tendency in the employment context and in the media).

114. See id. at 37-40.

115. See id. at 135,150 . In contrast, because masculinity, menace, or sexiness are associated with darkness, darker-skinned male actors are preferred over those with lighter skin tones for roles requiring these characteristics. Indeed, among Black men who obtain steady work in commercial films, most have medium to dark skin. See id. at 150.

116. See id. at $135,152-54,159$.

117. See id. at 154-57.

118. See Hughes \& Hertel, supra note 10, at 1116-17. 
reemerging. ${ }^{119}$ As before, the most likely candidates to fulfill this function are those who appear closer to White. ${ }^{120}$

2. Colorism Within the Black Community. In the post-Civil War era, skin color differences continued to play an important role within the Black community, as elite mulattoes ${ }^{121}$ sought to maintain the privileged status they had acquired during slavery. In order to distinguish themselves from the darker-skinned masses, these mulattoes established separate communities in which skin color served as the key to access. Mulattoes formed exclusive social clubs, like the Blue Vein Society of Nashville, ${ }^{122}$ and created separate churches. ${ }^{123}$ In the former, admission was based upon whether an applicant's skin color was light enough for the veins in the wrist to be visible. ${ }^{124}$ In the latter, the paper bag test was sometimes employed to determine admissibility. Under that test, persons seeking to join a

119. This trend may explain some White support for the modern Multiracial Category Movement ("MCM"). See Tanya Katerí Hernández, "Multiracial" Discourse: Racial Classifications in an Era of Color-Blind Jurisprudence, 57 MD. L. REV. 97, 131-33 (1998) (explaining how "the fear of demographic suffusion ... partially derives the burgeoning White interest in the multiracial category"); see also Gilanshah, supra note 104, at 197-99 (asserting that creation of a multiracial category may "lead to significant positive inter-group consequences in which mixed individuals may act as sensitive, objective negotiators of inter-group racial conflict"); infra Part II.B.3 (discussing the MCM and its implications for skin color discrimination).

120. See infra Part II.B.3.

121. ZACK, supra note 49 , at 95 . The mulatto elite consisted of "visibly mixed-race blacks, including blacks who looked completely white." Id. Professor Zack notes that this elite included "generations of higher education, economic security, and social refinement in its families.... The members of this caste had the best chance of passing for white-they knew more about white culture than the mass of blacks and had more contact with whites." Id. at 95-96.

122. See RUSSELl ET AL., supra note 2, at 25. These clubs were patterned after White clubs. See LANDRY, supra note 83, at 34 . Professor Landry notes:

The main objective of all these clubs was social, and members regularly entertained in lavish style with parties, dinners, dances, and teas and in general tried to pattern their lives after upper-middle-class whites. A great deal of emphasis was placed on white values and the imitation of affluent whites, an attitude that inclined the black elite to avoid contact with the rank-and-file of black society and to withdraw within the narrow circle of friends and relatives.

$I d$. In general, the Black elite displayed great "disdain for, and embarrassment at, the life style of darker blacks." Id. at 35. Although admission was technically based upon pedigree (e.g., being born into an upper class family), most of the members of these societies were of lighter skin tones because of their White ancestry. As Professor Landry discusses: "Membership in the emerging black elite depended less on economic means or occupation than on such characteristics as family background, particularly white ancestry, skin color, and manners and morals patterned after middle- and upper-class whites." Id. at 29.

123. See RUSSELL ET AL., supra note 2, at 27-28 (detailing the emergence of "color conscious" congregations).

124. See id. at 25 . 
color-conscious congregation were required to place their arm inside of a brown paper bag and could attend church services only if the skin on their arm was lighter than the color of the bag. ${ }^{125}$ Mulattoes also lived in separate residential communities like the Chatham and East Hyde Park sections of Chicago, and the Striver's Row and Sugar Hill areas of New York, which were known to be populated by lightskinned professionals. ${ }^{126}$ In addition, mulattoes formed separate professional and business associations. ${ }^{127}$ One of the most important areas in which mulattoes received superior treatment to darkerskinned Blacks was in education. Mulattoes formed preparatory schools and colleges that denied access to persons who were too dark. ${ }^{128}$ Many historically Black colleges and universities established in the nineteenth century also discriminated on the basis of color in their admissions process. ${ }^{129}$ Not only were educational institutions segregated by color, but their curricula differed as well. In schools attended by mulattoes, students received a liberal arts education. By contrast, darker-skinned Blacks were taught in schools and programs that focused primarily on vocational learning. ${ }^{130}$ This focus on training in practical skills reinforced the placement of darker-skinned Blacks into lower-paying, less-skilled positions.

Thus, at the turn of the century, the class of successful Blacks was largely comprised of the visibly-mixed population. These differences were reflected in the leadership of the Black community, where mulatto elites also dominated the intellectual and political life. ${ }^{131}$ Indeed,

125. See id. at 27.

126. See id. at 25-26. Congressman Adam Clayton Powell, Sr., observing Striver's Row in the 1940s, wrote:

[I]n Strivers Row ... were the dowagers of Harlem's society. These queenly, sometimes portly, and nearly always light-skinned Czarinas presided over the Harlem upper class. ... There was an open door for all who were light-skinned and for most of those of the professional group. The entire pattern of this society was white.... [And] if invited Harlemites brought with them [to a social function] their darker-skinned friends, they were shunned and sometimes pointedly asked to leave.

Jervis Anderson, This Was Harlem: A Cultural Portrait, 1900-50, at 340 (1982).

127. See RUSSELl ET AL., supra note 2, at 30-31.

128. See id. at 28-29.

129. See id. (noting the existence of such policies at Atlanta University, Fisk University, Howard University, Spelman Women's College, Wilberforce University, and, what are today, Hampton University and Morgan State University).

130. See id. (explaining that darker-skinned Blacks received vocational training because a liberal arts curriculum would not prepare them for the only jobs that were as a practical matter open to them).

131. See RUSSELL ET AL., supra note 2, at 24-25; ZACK, supra note 49, at 95-96. 
of the twenty-one men and two women among W.E.B. Du Bois's Talented Tenth, ${ }^{132}$ all were mulatto save one. ${ }^{133}$

Although the mulatto elite were generally in a higher socioeconomic class than unmixed Blacks due to their historically favored status, ${ }^{134}$ they were nonetheless rejected by the White community because of their Black blood. ${ }^{135}$ In addition, their lighter skin and better socioeconomic status spawned resentment within the Black community. ${ }^{136}$ Some of this resentment may have been fueled by the practice of passing, whereby light-skinned Blacks who looked sufficiently White would conceal their Black ancestry and pretend to be White. ${ }^{137}$ For the most part, however, the mulatto elite was admired by Blacks

132. The Talented Tenth referred to a small number of mostly northern, urban, collegeeducated men and women who had descended from relative privilege and who Du Bois believed would lead the Black race to greatness. See W.E.B. Du Bois, The Talented Tenth, reprinted in Henry Louis Gates, JR. \& CORNEl West, The Future OF THE RACE 133 (1996).

133. See RUSSELl ET AL., supra note 2, at 31-32.

134. See id. at 24; see also ZACK, supra note 49, at 95-96 (describing the "mulatto elite" as "economically and culturally advantaged").

135. See ZACK, supra note 49, at 95 .

136. A reverse dynamic occurs in some segments of the Black community where lighterskinned Blacks may be ostracized for not being sufficiently dark, or "Black enough." Baynes, supra note 23 , at 226 . In addition to skin color, a person may be considered insufficiently "Black" if the person is "too light-skinned, too middle class, too refined, too conservative politically ... too well educated.... foreign born or ha[s] too many White affiliations, such as a spouse or friends." Id. Professor Baynes recounts an incident where faculty members at Northwestern Law School utilized these criteria in arguing that a potential faculty hire should not be considered Black because she was not "'African American and [was] not Black in the U.S. context."' Id. (quoting Jan Crawford Greenburg et al., Race Issue Sparks Hiring Controversy at NU Law School, CHI. TRIB., Dec. 13, 1994, at 3). The candidate's parents were (White) Australian and (Black) Cuban. See id. Her economic background also suggested to some that she was not "Black enough." Id.

137. Passing, the option for a mixed person to identify herself as White, could be accomplished by people with "light skin, sharp features, and smooth hair." SPICKARD, supra note 30, at 333. The practice of passing is well-known throughout the Black community and is documented in both literature and film. See, e.g., Jessie R. FAuset, Plum Bun: A NOVel WITHOUT A MORAL (1928) (telling the tale of a young Black woman who seeks a better life by passing for White); LANGSTON HUGHES, Passing, in THE WAYs OF WhITE FOLKS 51 (1990); Nella LaRSEN, PAssing (1929) (chronicling the life of a light-skinned Black woman whose White husband is unaware of her race); DEVIL IN A BLUE DRESS (TriStar Pictures 1995) (depicting a White male who ends a relationship with his fiancée upon learning that she was passing for White); IMITATION OF LIFE (Universal International Pictures 1959) (recounting a story of an a Black housekeeper and her lighter-skinned daughter who rejects her mother and her race). For recent accounts by individuals whose families passed for White, see SHIRLEE HAIZLIP, THE SWEETER THE JUICE: A FAMILY MEMOIR IN BLACK AND WHITE (1994) (detailing the author's investigation of her family's history, some of whose members passed for White); GREGORY H. Williams, LIFE ON THE COLOR LINE: THE TRUE STORY OF A WHITE BOY WHO DisCOVERED HE WAS BLACK (1996) (chronicling the author's discovery of his racial identity). 
and, throughout the early part of the twentieth century the bond among Blacks of all skin tones grew. ${ }^{138}$

The alliance between mixed and unmixed Blacks was further strengthened during the Black Power movement of the 1960s. ${ }^{139}$ That movement revived the affirmation of Blackness that had characterized the Harlem Renaissance. The celebration of all things Black (e.g., "black pride, black beauty, black achievement, black history, and the use of the term 'black' rather than 'Negro'",140) comprised a major portion of the agenda of the Black Power movement. On the surface, skin color differences seemed less important as light- to medium-skinned Blacks like Andrew Young, Jesse Jackson, Julian Bond, Adam Clayton Powell, Jr., and Angela Davis joined forces with darker-skinned leaders like Eldridge Cleaver, Stokely Carmichael, and Huey Newton. Still, at the same time that "Black unity" was the rallying cry of the movement, lighter-skinned Blacks were sometimes ostracized and made to feel as if they had to prove their Blackness. The perceived demand for lighter-skinned Blacks to prove their loyalty was due to a learned mistrust, which may have been fueled by the fact that some lighter-complected persons had historically rejected their status as members of the Black race because of feelings of superiority or out of an effort to improve their socioeconomic standing in society. ${ }^{141}$

Throughout the 1970s, some members of the Black community continued to view disfavorably lighter-toned Blacks. These individuals were stereotyped as morally weak and mentally unstable because of their mixed-racial heritage. ${ }^{142}$ They were also accused of thinking

138. See ZACK, supra note 49, at 98 (noting that although "people of visible mixed race were devalued by both blacks and whites ... the broader cultural identity of all blacks brought the protection of a much larger group than a mere 21 percent of what was already a minority of 10 percent").

139. See DAVIS, supra note 25 , at 74 ("In the 1960s, growing black pride brought the lighter mulattoes into an even closer alliance with blacks in general than the Black Renaissance of the 1920s had produced.").

140. Id.

141. See id. (noting "the historical advantages of lightness"); see also MAUREEN REDDY, CROSSING THE COLOR LINE 80-82 (1994) (discussing the early advantages of light skin, particularly among Black women, and the resentment that developed among darker-skinned women); ZACK, supra note 49, at 124 ("Blacks were always suspicious of mulattoes who came from old exclusive families that had been free before the Civil War. According to the black stereotype, these mulattoes kept themselves aloof from other blacks and thought they were superior to them.").

142. See DAVIS, supra note 25 , at 133 (using the term "high yaller" to indicate that "very light mulattoes have often been considered illegitimate and trashy" and describing a "very light mulatto's" experiences with people becoming uncomfortable at the idea that he does not know 
that they were more intelligent and attractive than unmixed Blacks. ${ }^{143}$ Despite these negative critiques, if a lighter-toned person exhibited allegiance to Black causes and embraced her Black heritage, darker Blacks usually accepted her into their extended family. ${ }^{144}$

The above history has affected contemporary relations within the Black community where evidence of colorism still exists. When their guards are down, many Blacks will readily share stories involving intraracial colorism. ${ }^{145}$ As is the case within the White community, the dominant preference operates in favor of lighter skin tones. Researchers have found that when asked to choose from a selection of White and Black dolls, Black children tend to select White dolls. ${ }^{146}$

"what he is"); SPICKARD, supra note 30 , at 330 (noting the stigma of illegitimacy attached to mulattoes "who were frequently accused of thinking themselves smarter, more beautiful, and generally better than other blacks").

143. See SPICKARD, supra note 30, at 330.

144. See id. at 330 ("Most black people seemed willing to accept mulattoes into their communities so long as they committed themselves to other blacks and did not go chasing after whites.").

145. From my own experience, colorism was never discussed at length among my friends and family. We were, however, all aware of the phenomenon and it sometimes affected the ways in which we lived our lives and interacted with each other. For example, I vividly recall warnings issued at various times among friends and family members not to spend too much time in the sun, lest the recipient of this "advice" become too dark. I also recall that during childhood one of the cruelest utterances that could be leveled at my middle sister, who is a shade darker than medium brown, was the statement "You're so black, you're blue." At the time, I was too young to understand the implications of this comment. Yet, implicit in all of the above statements is the belief that there is something "wrong," something profoundly negative, about being too dark. In talking with other family members and friends about the substance of this Article, I have been regaled with stories about colorism (too many to recount here). Both my mother, who came of age in the 1960s, and my 83-year-old neighbor, who witnessed much of the twentieth century, recall vividly a society divided by skin color, a society in which the governing principle was "if you're white, you're all right, if you're brown, stick around, and if you're black, stand back." Conversations between Trina Jones and Hattie Jones (Mar. 2, 2000 and Mar. 22, 2000); Conversation Between Trina Jones and Loris Ray (Mar. 2, 2000).

Recently, my 22-year-old darker-toned research assistant, who self-describes as mocha, told me that when she was young, she spent a lot of time playing outdoors. As a result, her skin would become quite dark. She recalls that when she returned to school, if her skin had darkened significantly, her classmates would sometimes shy away from her as if they were afraid. She also recalls being told often during the course of her young life, "You are pretty for a dark girl." She notes that this comment always made her question, "Why can't I just be pretty?" Conversation Between Trina Jones and Stacey-Ann Taylor (May 31, 2000). For additional personal accounts of intraracial colorism, see generally RUSSELL ET AL., supra note 2; SKIN DEEP, supra note 4.

146. See Kenneth B. Clark \& Mamie P. Clark, Racial Identification and Preference in Negro Children, in READINGS IN SOCIAL PSYCHOLOGY (Eleanor E. Maccoby et al. eds., 1947) In the Clark experiment, children ages three through seven were asked to choose among dolls with varying skin colors; the purpose was to reveal the children's racial preferences, their awareness of racial differences, and their racial self-identification. See id. passim. For a critique of the Clark study, see J.A. Baldwin, Theory and Research Concerning the Notion of Black SelfHatred: A Review and Reinterpretation, 5 J. OF BLACK PsYCH. 51, 60-69 (1979) (noting alterna- 
Black men tend to prefer lighter-skinned women as intimate companions. ${ }^{147}$ Blacks with lighter skin tones also fare better educationally and economically than darker Blacks. ${ }^{148}$ Indeed, since the 1960 s, most Blacks elected or appointed to prominent governmental positions have had light skin.

Colorism among Blacks does not operate uniformly in favor of persons with lighter skins. Indeed, some Blacks with darker skin pigmentation distrust and have expressed hostility towards Blacks with lighter skin tones. ${ }^{150}$ For example, when Sharon Pratt Dixon ran for mayor of Washington, D.C., some Blacks questioned whether this light-skinned Black woman could understand the issues that affected

tive theories to explain the results). There is some evidence that children can be socialized to think differently about color. See Darlene Powell-Hobson \& Derek S. Hobson, Implications of Doll Color Preferences Among Black Preschool Children and White Preschool Children, 14 J. OF BLACK PSYCH. 57 (1988) (discussing racial prejudice and its effects on children). In addition, it is not clear whether the influx of Black dolls in the children's toy market over the last decade would impact child preferences were the tests performed today. See RUSSELL ET AL., supra note 2 , at $64-65$.

147. See Itabari Njeri, Colorism in American Society, Are Lighter-Skinned Blacks Better Off?, L.A. TIMES, Apr. 24, 1988, available in 1988 WL 2267696. For extensive analysis of the role of colorism in dating preferences, see RUSSELL ET AL., supra note 2, at 107-23 (describing a preference that women be lighter and discussing the difficulties of interracial dating).

148. See supra note 10.

149. Russell et al. note the success of light-skinned Blacks leaders including:

Robert Weaver, secretary of the Department of Housing and Urban Development, and the first Black U.S. cabinet member (1966); Edward W. Brooke, the first Black senator since Reconstruction (1966); Thurgood Marshall, the first Black Supreme Court justice (1967); Maynard Jackson, the first Black mayor of Atlanta (1974); Andrew Young, the first Black U.S. ambassador to the United Nations (1976); Patricia R. Harris, the first Black woman cabinet member (1976); Ernest Morial ... the first Black mayor of New Orleans (1977); David Dinkins, the first Black mayor of New York (1989); Douglas Wilder of Virginia, the first Black governor (1989); General Colin L. Powell, the first Black chairman of the Joint Chiefs of Staff (1989); Ron Brown, the first Black to chair the Democratic National Committee (1989); Sharon Pratt (Dixon) Kelly, the first Black female mayor of a major city, Washington, D.C. (1990).

RUSSELL ET AL., supra note 2, at 36-37. Of course, there are a few notable exceptions to the above pattern, "including Shirley Chisholm, the first Black congresswoman (1968), Barbara Jordan, a congresswoman from Texas (1972), Harold Washington, the first Black mayor of Chicago (1972), Maxine Waters, a congresswoman from California (1990), and Supreme Court Justice Clarence Thomas (1991)." Id. at 37. Nonetheless, the perception lingers that "[t]hose who are light skinned have a better chance at succeeding in politics and business." Id.

150. See DAVIS, supra note 25, at 74 ("In the 1960s, lighter persons in general often felt they had to prove their loyalty to the black community, and some complained of discrimination from other blacks."); WILLIAMSON, supra note 27, at 190 ("Very light mulattoes, mulattoes who could pass for white, frequently suffer from an extreme discrimination within the Negro world."). 
them. ${ }^{151}$ Similarly, when Vanessa Williams was crowned as the first Black Miss America, some Blacks criticized the pageant for selecting someone who was not "Black enough."

Although colorism has existed within the Black community for centuries, we have for the most part stopped employing different labels for persons who are different shades of brown. In recent years, however, there have been growing signs of fission within the Black community. This trend is evident in the modern Multiracial Category Movement ("MCM"). Demographic evidence indicates that the primary proponents of this new category are biracial (Black-White) persons or monoracial (Black or White) parents acting on behalf of their biracial children. ${ }^{153}$ Because the MCM involves the creation of a separate racial category (or intermediate category) of mixed-race people whose lighter brown skin tone is one of their more distinguishing physical features, it is important to discuss briefly the implications of this movement on contemporary colorism. ${ }^{154}$

3. The Multiracial Category Movement and Colorism. The Multiracial Category Movement originated in the 1980s when parents

151. See RUSSELl ET AL., supra note 2, at 39; see also Effi Barry Reveals: Mayor Wanted Her Skin Darkened to Protect His Image as a Black Man, JET, July 23, 1990 (detailing efforts of a former Washington, D.C. mayor to have his wife darken her skin because of concerns that her "lightness" might harm his political appeal).

152. See Jack Kroll, Success is the Best Revenge, NEWswEEK, Aug. 15, 1994, at 65 (quoting Williams's statement that "I got hate mail from white-supremacist groups and also from blacks who didn't feel I was black enough”); Courtland Milloy, Black Beauty, WASH. POST, Sept. 22, 1983, at DC1 (noting that "Williams's victory serves only as a bittersweet confirmation that the lighter your skin, the better your chances of being accepted"). Of course, many in the Black community applauded Ms. Williams's accomplishment. See, e.g., Susan Chira, First Black Miss America Finds Unforeseen Issues, N.Y. TIMES, Apr. 3, 1984, at B1 (recounting instances of praise from Black individuals); Natalie Oliver-Vick, Mail, PeOPLE, Nov. 14, 1983, at 4 ("I am tired of people ... complaining that Vanessa Williams doesn't look black enough.”).

153. See Hernández, supra note 119, at 106.

154. Although there will be situations in which a person's multiracial identity can be deduced from knowledge of the race of her parents, that information is not always available to the viewer. Outside of a certain sphere, people do not know the race of other people's parents (especially in an increasingly mobile society where individuals often live in geographical areas that are far removed from the homes of their parents). Thus, in everyday interactions on the job, at the health club, in the supermarket, etc., multiracial individuals are more likely to be identified as multiracial because of their skin color, hair, etc. If a person is sufficiently dark, she will be considered Black. If she is sufficiently light, then she will be considered White. If she is in between these two extremes, then she may be considered multiracial. As an aside, it will be interesting to watch over time to see whether first-generation multiracials will be subsumed into existing racial groups if they do not marry other multiracials. In other words, if a multiracial individual marries someone who is Black, will their offspring be considered Black or multiracial? 
of biracial children began to challenge identification criteria on school data forms. ${ }^{155}$ By the 1990 s, multiracial category advocates had shifted most of their energy to a campaign to secure the addition of a multiracial category on decennial census forms for the year $2000 .{ }^{156}$ Their efforts were ultimately unsuccessful. ${ }^{157}$ The debate concerning racial categories, however, extends well beyond census classifications.

Although it is difficult to reduce such a controversial and complex topic to a few words, multiracial category proponents appear to believe that the category will: (1) challenge the use of racial categorization by forcing society to acknowledge that race is too fluid to monitor in an increasingly diverse society; ${ }^{158}$ (2) promote racial harmony by identifying a group that is capable of bridging the gap between Blacks and Whites, ${ }^{159}$ and (3) allow mixed-race persons to selfidentify and to acknowledge all aspects of their racial heritages. ${ }^{160} \mathrm{Al}-$

155. See Hernández, supra note 119 , at 107.

156. Census forms now permit individuals to select from among five general racial classifications: American Indian or Alaskan Native, Asian or Pacific Islander, Black, White, or Other. See U.S. DeP'T OF Commerce, Bureau of The Census, U.S. Census 2000, Form D-1 (2000). The forms also contain a separate Spanish/Hispanic/Latino ethnicity question, which is not considered a racial category. These categories are assigned and implemented by the U.S. Office of Management and Budget ("OMB") through Statistical Directive Number 15. See Office of Management and Budget, Stat. Dir. No. 15, 43 Fed. Reg. 19269-70 (1977). For detailed discussion of the history of efforts to change census classifications, see Jennifer D. Williams, Race and Ethnicity: Possible Revision of OMB's Classifications, in AfFIRMATIVE ACTION: CATALYST OR AlBATROSS 227, 228 (S.N. Colamery ed., 1998).

157. In 1996, OMB refused to add a multiracial category to census schedules and elected instead to allow individuals to check multiple boxes on the forms. See Revisions to the Standards for the Classification of Federal Data on Race and Ethnicity, 62 Fed. Reg. 58,782, 58,78890 (1997) (explaining and defining categories for race and ethnicity that could "provide a common language for uniformity and comparability in ... collection and use of data").

158. See Alex M. Johnson, Jr., Rethinking the Process of Classification and Evaluation: Destabilizing Racial Classifications Based on Insights Gleaned from Trademark Law, 84 CAL. L. REV. 887, 891 (1996). Professor Johnson argues that

[I]n order to deconstruct this harmful racial dichotomy ... society should embrace, as a transitory vehicle, multiple racial categories that expressly recognize and acknowledge products of mixed-race unions as distinct from both blacks and whites. ... [T]his will have the effect of creating a type of "shade confusion" which will eventually destroy the black/white dichotomy that currently exists, ultimately reducing race to a meaningless category, as it should be.

Id.

159. See, e.g., Gilanshah, supra note 104, at 197 (concluding that recognition of the multiracial community would "lead to significant positive inter-group consequences in which mixed individuals may act as sensitive, objective negotiators of inter-group conflict").

160. Some multiracial category advocates argue that mixed-race persons are psychologically unable to identify with just one racial category. See id. at 189-90 (discussing the need for multiracial individuals to be able to "clam and maintain [their] distinctive dual-self"); Julie LythcottHaims, Where Do Mixed Babies Belong? Racial Classification in America and its Implications for Transracial Adoption, 29 HARV. C.R.-C.L. L. REV. 531, 539-43 (1994) (noting that it is 
though one can understand the appeal of and the potential merit to these claims, proponents fail to engage sufficiently the complex history and present reality of colorism. ${ }^{161}$

The first argument - that a multiracial category will eliminate racial classification altogether and move society beyond racial divisions-is debatable. The adoption of a multiracial category is equally

common for multiracial children to be raised as Black); Michael K. Frisby, Black, White or Other, EMERGE, Jan. 31, 1996, at 48 (describing how a social security officer changed a form listing race as "biracial" to "Black"). These advocates point to the number of people checking the "Other" box on census forms as evidence of the inability of current racial classifications to reflect the needs of mixed-race persons. However, studies show that the vast majority of those individuals are Latinos for whom the census does not provide a racial category. See, e.g., Clara E. Rodriguez, Race, Culture, and Latino "Otherness" in the 1980 Census, 73 Soc. SCI. Q. 930, 930 (1992).

161. Multiracial category advocates also assert that the use of a multiracial category on census forms would produce a more accurate count of mixed-race persons. This claim is curious and is indeed susceptible to multiple interpretations. If it is true that the vast majority of Blacks in America are, and have historically been, of mixed-racial heritage, then should everyone check the multiracial box? See Lawrence Wright, One Drop of Blood, NEW YORKER, July 25, 1994, at 46,48 (reporting census estimates that $75 \%$ of those who currently identify as Black could identify as multiracial); see also CARL N. DEgLER, NeITHER BLACK NOR WHITE: SLAVERY AND RACE RELATIONS IN BRAZIL AND THE UNITED STATES 185 (1986) (reporting an estimation that "between three-quarters and four-fifths of all [Blacks] in the United States have some [W] hite ancestry"); Maria P.P. Root, Within, Between, and Beyond Race, in RACIALLY MIXED PEOPLE IN AMERICA 3, 9 (Maria P.P. Root ed., 1992) (estimating that 30-70\% of AfricanAmericans are multiracial by multigenerational history, and that virtually all Latinos and Filipinos are multiracial, as are the majority of American Indians and Native Hawaiians). If the category does not apply to everyone, then to whom does it apply? Would it include Asian-White combinations as well as Latino-Black combinations? Does the mere fact that their racial identity is comprised of two or more different races justify placing these groups in the same category? Does the category apply equally to a first-generation biracial and a fourth-generation multiracial? On what basis? In any event, does not this entire method of analysis ignore the sociopolitical dimensions of race and serve to reduce race to a question of biology? See Hickman, supra note 50, at 1222-31 (discussing the dangers inherent in purely biological definitions of race).

Admittedly, the point may be that everyone is multiracial and therefore that talk of race and racial classifications makes no sense. Under this theory, the focus would not be on having a variety of different boxes from which to choose, but rather on the elimination of boxes and races altogether. The problem with this proposed solution is that in order to eradicate racism, one must have a mechanism (i.e., racial classifications) for identifying races in order to monitor social progress. See Williams, supra note 156, at 227-28 (noting that standardized terms for racial categories are used by the government to collect data necessary to monitor compliance with the Civil Rights Act, the Equal Credit Opportunity Act, the Fair Housing Act, the Voting Rights Act, and various other affirmative action and school desegregation efforts). By eliminating existing racial categories, the multiracial category approach gives the illusion that race is no longer important without affording a mechanism for testing this proposition. The work of Lewis Killian illustrates this point. In short, Killian argues that because races do not exist, racial classification should be banished from our minds. This would include the elimination of laws and policies designed to achieve racial remediation, like affirmative action programs. See Lewis Killian, Black Power and White Reactions: The Revitalization of Race-Thinking in the United States, 454 ANNAls AM. ACAD. POL. \& SOC. SCI. 43 (1981). 
likely to contribute to the proliferation of racial categories rather than to their elimination. Even assuming, arguendo, that a multiracial category will cause society to recognize that race is too fluid to monitor, this claim assumes that along with racial classifications, discrimination will also disappear. ${ }^{162}$ But, one event need not follow the other. The fact that racial labels may no longer be handy does not mean that discrimination will disappear. Rather, the virus of discrimination may simply mutate or find another host. Because skin color has been used historically as a basis for subordination in this country, skin color may provide an alternative site. That is, in the future, skin color differences may increasingly perform the role played by racial categories today. In this new social context, multiracial individuals and other persons of color will still be subject to discrimination on the basis of skin color to the extent that their skin is too dark or too light.

The second argument - that a multiracial category will produce an identifiable class of people who will facilitate interracial communications between Blacks and Whites-sounds like a modern-day appeal for a buffer class (a class distinguishable by its lighter skin tone). In the United States, however, buffer classes have not historically acted as catalysts for interracial harmony. Rather, they have served to increase the status of those in the middle (the buffer class) without fundamentally challenging the status quo for those on the top and bottom. $^{163}$ In Brazil and Latin American countries where buffer classes have existed historically, the same dynamic has occurred. ${ }^{164}$ Thus, while tending to improve the lot of some, buffer categories fail to challenge existing racial and color hierarchies. In future discussions, proponents of a multiracial category must come forth with evidence that history will not repeat itself in the current context. In short, they must explain how a multiracial category will avoid simply reinforcing the existing racial and color hierarchy.

162. I do not mean to suggest that that the manipulation of labels will have no positive effects in destabilizing the hegemony of racism (or colorism). See generally Johnson, supra note 158. I simply question the extent to which a change in labels will solve the problem of discrimination-whether that discrimination is practiced through racism or colorism.

163. See supra Part II.A.2.

164. See Hernández, supra note 119, at 121-39 (explaining how mixed-race buffer classes in Brazil, Colombia, Cuba, Nicaragua, Panama, and Venezuela have historically maintained the system of White supremacy in those countries). 
The third argument-that a multiracial category will allow mixed-race persons to self-identify ${ }^{165}$ and to acknowledge the totality of their racial heritages-is intuitively appealing. It seems that a goal of multiracial category proponents is to challenge the continued application of the one-drop rule (e.g., the notion that a person is Black if she has a trace of blackness in her physical appearance or in her ancestry). Again, this goal seems fair, neutral, and perhaps even laudable. However, as I explain below, an unintended consequence or negative externality of this objective must be considered: mixed-racial heritage and skin color may operate to elevate the status of lighterskinned multiracial individuals, while doing nothing to alleviate the subordination of those who are darker or to change the idea that Black is undesirable.

Briefly, in a sociopolitical context in which one drop of Black blood renders one Black, the desire not to choose one aspect of one's racial heritage over another in effect means that multiracials are seeking to acknowledge their White racial heritage. Although this desire appears neutral or egalitarian, it assumes a symmetry in the value placed on White and Black ancestry that does not exist. As Professor Hernández accurately observes:

[C]laims to different racial ancestries are not socially symmetrical in effect. That is to say, what the parents of biracial children may fail to

165. To the extent that multiracial category proponents argue that they have a personal right to identify themselves in any manner that they choose, they may be ignoring the sociopolitical nature of race and skin color differences. If she chose to do so, Oprah Winfrey could call herself White. By the same token, Rosie O'Donnell is free to label herself Black. There is undoubtedly an aspect of identification that is quite personal and over which individuals can and must have complete autonomy. The problem is that regardless of how they individually and personally define their identities, society will still view Oprah as Black and Rosie as White or as having skin tones that are different shades of brown. To that extent, race and skin color are constructs created by external societal forces and are not solely matters of individual preference. The fact that antidiscrimination law is concerned with the ways in which societal forces act upon individuals in a discriminatory fashion renders these social constructions more critical to the present analysis than personal expressions of identity. Professor Denton makes a comparable point. She writes:

[C] urrent categories result in some people, particularly those of mixed race, being "racially designated," which is not a very comfortable position. However, giving people a more accurate choice on the census or any other form, by itself, will do nothing to change the imposition of external identity. Regardless of how truly one is able to express one's personal identity, structural racism in U.S. society will persist in forcing people into one of the five boxes of the racial/ethical pentagon for the foreseeable future.

Nancy A. Denton, Racial Identity and Census Categories: Can Incorrect Categories Yield Correct Information?, 15 LAW \& INEQ. J. 83, 96-97 (1997) (citation omitted). 
perceive is that while the political acknowledgment of White racial ancestry can be beneficial to the individual child, it also unfortunately reinforces societal White supremacy when society places greater value on White ancestral connections than on non-White connections. "Whiteness is an aspect of racial identity surely, but it is much more; it remains a concept based on relations of power, a social construct predicated on white dominance and Black subordination." Thus, the symmetrical identity demand can also function as a claim to having biracial children inherit all of the privileges of White status, which White parents logically would like to extend to their children as protection from racism against non-Whites. ${ }^{166}$

Hence, in a social context where whiteness or lightness is valued more highly than blackness or darkness, what appears to be a quest for equivalency, can, in effect, result in an escape from blackness. ${ }^{167}$ Because their mixed racial heritage or lighter skin will enable mixedrace persons to access the privileges of whiteness or lightness, their strategy has the potential to reinforce or further entrench colorism. ${ }^{168}$

In conclusion, the dynamic propelling the MCM is strikingly similar to that which existed in parts of the Lower South in the seventeenth and eighteenth centuries at the height of racial mixing in the United States. Wealthy or upper-middle-class biracials (or their parents) are in effect creating a buffer class between White and Black. To the extent that these multiracials are Black-White biracials, one of the most readily identifiable characteristics of this class is its lighter skin tone. Because this characteristic is more highly valued in the United States than darker skin tone, it may afford them the opportunity to obtain better positions in the socioeconomic hierarchy. Unless proponents of a multiracial category address some of the difficult issues raised by colorism, the only real difference between 1800 and 2000 may be that the current category is labeled "multiracial" instead

166. Hernández, supra note 119, at 110-11 (quoting Cheryl I. Harris, Whiteness as Property, 106 HARV. L. REV. 1709, 1761 (1993)).

167. If Black did not carry negative connotations, there would be no need to flee from it. As one commentator has observed, "If the old saying 'one drop of Black blood makes you Black' were reversed to say one drop of White blood makes you White, would the biracials still be seeking a separate classification?" Mary Smith, Letter to the Editor, EBONY, Nov. 1995, at 298.

168. Indeed, as Professor Hickman notes, a multiracial category may in effect create a onedrop rule of its own: "one drop of White blood would transform a 'Black' person into a 'partBlack person of all hues.'” Hickman, supra note 50, at 1204; see also Hernández, supra note 119, at 121 (noting that "protective efforts [by] concerned White parents ... extend the supremacist system privilege to those who are viewed as 'practically-all-White' without actually dismantling the racial hierarchy itself"). 
of "mulatto." The negative consequences, however, will likely be the same. Those on the bottom will stay on the bottom. Those on top will remain on top. Only those in the middle will share the illusion of movement by virtue of their skin color. Unless antidiscrimination advocates realize that the evil is not racial classifications, or even skin color differences, but, rather, a system that attaches meaning to these variables in order to maintain existing inequality, true progress will not occur. ${ }^{169}$

\section{The Social Psychology of Contemporary Black-White Colorism}

As demonstrated above in Section B, skin color still matters in the United States. For many persons within both White and Black communities, light- to medium-brown skin is associated with intelligence, refinement, prosperity, and femininity. ${ }^{170}$ Darkness is associated with toughness, meanness, indigence, criminality, and masculinity. ${ }^{171}$ These meanings are historically based.

The association between skin color and class can be traced back to the early division between house slaves and field slaves and the fact that, due to the status of their White fathers, some light-skinned slaves were granted greater educational and professional opportuni-

169. One of my research assistants has jokingly referred to me as the "one-drop queen." I do not have a normative preference for or against the one-drop rule. It seems to me that the real problem is not the one-drop rule, but rather the social meaning afforded blackness. Were we to eliminate the rule, fewer people would be categorized as Black, but those whom society places within that category will still be subject to racial subordination. I am most concerned with eradicating that subordination. Unfortunately, for the reasons articulated above in the text, I am not convinced that a multiracial category will move us towards this goal. Professor Hickman similarly argues:

$[\mathrm{R}]$ ather than exploding the 'myth' of race or rebutting the stereotypes of what it is to be Black by including multiracial people within its definition, [the multiracial movement] distances itself from the 'full Black nigger[s],' unwittingly relying on the ideal that race is biological, ancestral, and blood-borne. Rather than challenge the notion of race, this branch of multiracial theory merely attempts to reset the margins ....

Hickman, supra note 50, at 1224.

170. In an unpublished study conducted at DePaul University, psychologist Midge Wilson found that both Blacks and Whites share negative attitudes about Black women with dark skin. In that study, Wilson asked approximately 80 people, evenly divided between males and females, Blacks and Whites, to characterize their impressions of the photographs of twelve Black women. She notes that "the study participants nearly always rated the dark-skinned women as less successful, less happy in love, less popular, less physically attractive, less physically and emotionally healthy, and less intelligent than their light-skinned counterparts." RUSSELL ET AL., supra note 2, at 67-68. Interestingly, Russell et al. note that "[t]he only quality in which the dark-skinned females were not rated lower was sense of humor, a phenomenon they labeled the 'Whoopi Goldberg effect.'” Id. at 68.

171. See id. at 66-69, 135 . 
ties. ${ }^{172}$ The higher socio-economic class of lighter-skinned Blacks may have made them appear less foreign and therefore less threatening to Whites. Their elevated status also may have rendered them more attractive to darker-skinned Blacks. To some extent, class-based distinctions are self-perpetuating because socio-economic advantages are passed down from one generation to another-with classism intensifying the effects of colorism. Skin color, however, functions as more than an indicator of class: a person's relative lightness or darkness determines whether she can access the benefits associated with a particular class. This phenomenon occurred in the post-Civil War era when elite mulattoes created social and political organizations into which access was granted or denied based upon one's skin color regardless of one's actual socio-economic class. ${ }^{173}$ Thus, persons whose skin was light enough were allowed entry even if they were poor. Conversely, wealthy persons were denied access if their skin was too dark. In these circumstances, skin color itself served as the determinant of status regardless of a person's actual socio-economic class.

The meaning attributed to skin color today does not rest merely upon historical class-based differences between light-skinned Blacks and darker-skinned Blacks-as the darkening of O.J. Simpson's photo illustrates. ${ }^{174}$ Although it is hard to prove, contemporary colorism also appears to draw upon concepts of good and evil that predate European colonization of North America. In the European tradition, "whiteness" or "fairness" is associated with purity and innocence, and "blackness" is associated with dirt, evil, and death. ${ }^{175}$ Con-

172. See supra notes 81-83 and accompanying text; see also Bonnie Allen, It Ain't Easy Being Pinky, EsSENCE, July 1982, at 67-68.

173. See supra notes 121-38 and accompanying text.

174. See Time Magazine Darkens and Blurs O.J. Simpson Mug Shot, Assoc. Press, June 21, 1994, available in 1994 WL 10150984 (noting that Time and Newsweek both used Simpson's mug shot, but that Time had an artist darken and blur the face, but not, according to a Time spokesperson, in an effort to mislead); see also Edgar Allen Beem, Byting the hand that heeds them, MAINE TIMES, May 12, 1995, at 16 (referencing Time magazine's decision to "digitally darken O.J. Simpson's complexion to make him look more sinister").

175. See Winthrop Jordan, White Over Black 7-11 (1968); Francois Raveau, An Outline of the Role of Color in Adaptation Phenomena, in COLOR AND RACE, supra note 4, at 98, 119-20. There is reason to believe that these associations continue in Europe today. As Frantz Fanon notes:

In Europe, the black man is the symbol of Evil. One must move softly, I know, but it is not easy. The torturer is the black man, Satan is black, one talks of shadows, when one is dirty one is black-whether one is thinking of physical dirtiness or of moral dirtiness. It would be astonishing, if the trouble were taken to bring them all together, to see the vast number of expressions that make the black man the equivalent of 
temporary beliefs that lighter-skinned persons are more attractive than darker-skinned individuals, or that darker-skinned persons are more evil or criminal than their lighter counterparts, may relate to these traditions. ${ }^{176}$

Finally, because skin color is often an indicator of mixed-racial heritage, contemporary colorism may draw upon racism and nineteenth-century ideologies of race. ${ }^{177}$ Here, the argument is that Blacks with lighter skin tones are superior to Blacks with darker skin tones because of the former's White ancestry; lighter-skinned Blacks, however, are nonetheless inferior to Whites because their heritage is not completely White. Thus, a White person might view a lighter-skinned

\footnotetext{
sin ... Blackness, darkness, shadow, shades, night, the labyrinths of the earth, abysmal depths, blacken someone's reputation; and, on the other side, the bright look of innocence, the white dove of peace, magical, heavenly light. A magnificent blond child-how much peace there is in that phrase, how much joy, and above all how much hope! There is no comparison with a magnificent black child: literally, such a thing is unwonted.
}

FRANTZ FANON, BLACK SKIN WhITE MASKs 188-89 (1967). Interestingly, preferences for light colors have existed in other societies as well. See, e.g., Horoshi Wagatsuma, The Social Perception of Skin Color in Japan, in COLOR AND RACE, supra note 4, at 129 (observing that the Japanese viewed white skin as beautiful and dark skin as ugly long before any sustained contact with Europeans, Africans, or Indians); see also RUSSELL ET AL., supra note 2, at 57 (noting that thousands of years ago in Central America, "Aztec women during courtship [would] smear themselves with an ointment made of yellow earth, since golden skin was considered more attractive than brown").

176. See RUSSELl ET AL., supra note 2, at 66-68, 107-09, 135 (describing contemporary examples of the historical notion that lighter skin is preferable to darker skin); see also Veronica Chambers, The Essence of Susan Taylor, RALEIGH News \& OBSERVER, June 18, 1995, at E1 (quoting Susan Taylor, the editor-in-chief of Essence magazine, as recognizing that "[f]or so long the beauty standard for black women dictated that if you didn't have light skin and long (straight) hair then you weren't attractive. It made a tremendous impact for Essence to put a brown-skinned woman on the cover and say this is beautiful"); Bill Underwood, Many ColorsAfrican Americans Explore Racism in Black Community, TULSA WORLD, Feb. 26, 1997, Central Tulsa Zone 1 (describing a "black-on-black caste system ... founded on the idea that light skin is more attractive than dark skin").

177. See DAVIS, supra note 25, at 25. Davis notes that racist ideologies consist of five principle beliefs: (1) "some races are physically superior to others" as measured by "differences in longevity and rates of certain diseases"; (2) "some races are mentally [or intellectually] superior to others"; (3) "race causes culture," or "each inbred population has a distinct culture that is genetically transmitted along with its physical traits"; (4) "race determines temperamental disposition of individuals"; and (5) "racial mixing lowers biological quality." Id. at 23-25. He notes that it is not surprising that people consider miscegenation dangerous

when they also believe that physical, mental, and behavioral traits are all tied to racial heredity, and when they make the value judgment that their own culture is far superior to others. The mixing of what are presumed to be superior stocks with inferior and detested stocks allegedly leads to blood poisoning and other physical deterioration, to mental inferiority, and to immorality and cultural degeneracy.

$I d$. at 25. Davis, however, points out that there is no scientific proof that race-mixing either lowers or increases the biological quality of either of the co-mingled races. See id. 
Black as preferable to a darker-skinned Black because of her allegedly closer connection to Whiteness. The infusion of White blood may lead Whites to conclude that lighter-skinned Blacks are more intelligent and capable than darker Blacks. ${ }^{178}$ To the extent that people of color have been socialized to accept these racist norms, they may also unconsciously view lighter-skinned Blacks as being racially superior. ${ }^{179}$ This argument also works in the reverse. A Black person might view a light-skinned person as inferior to darker Blacks because of her mixed ancestry. Thus, instead of elevating her worth, her White ancestry would diminish her value within the Black community. ${ }^{180}$ This response may be a defense against the dominant tendency to prize White racial heritage; that is, it may be an effort to counter the stigma of not being White enough. It also may be a form of reverse racism; that is, a manifestation of the belief that visibly unmixed Blacks are culturally and intellectually superior.

In sum, a variety of sociological and psychological factors converge to give skin color the meaning it has today. Colorism may arise from, among other things, racist ideology, class-based assumptions, the symbolism of the colors white and black, or from a combination of these things. Often, it is impossible to sort out which factor may be at work in any given situation. Understanding the complexity of colorism, however, is essential if we are to comprehend our increasingly diverse society. This knowledge may help us to understand why the skin of a famous Black pop music superstar has increasingly lightened over time ${ }^{181}$ why former President George Bush used a dark-skinned Black male criminal in television ads designed to challenge his oppo-

178. See supra note 92 and accompanying text.

179. For a discussion of the causes of colorism within the African-American community, see Johnson, supra note 158, at 903-06; C. Eric Lincoln, Color and Group Identity in the United States, in COLOR AND RACE, supra note 4, at 249, 253-54.

180. See Williamson, supra note 27, at 190 ("Whereas the problem for mulattoes used to be 'not white enough' to be accepted in the white world, now the problem, sometimes, is 'too white' to be accepted in the 'black' world."); see also Baynes, supra note 23, at 98-100 (recounting the controversy over Northwestern University's decision not to hire a female professor who was deemed by some to not be "black enough"); supra notes 136-44, 150-52, and accompanying text.

181. See Tananaive Due, Bleached? Jacksons are Hardly Alone, ARIZ. RePUBLIC, Dec. 4, 1991, available in 1991 WL 6055746 (commenting upon the lightening of Michael Jackson's skin over the years and his sister's argument that the cause was lupus); Gary Mays, No Cure for Jackson's Disease, THE PANTAGRAPH, Mar. 1, 1993, available in 1993 WL 4327253 (reporting Jackson's revelation to Oprah Winfrey that he suffers from a skin disorder that has caused his skin to lose pigmentation). 
nent's "toughness" on crime, ${ }^{182}$ why Time magazine darkened its cover photo of O.J. Simpson during his criminal trial, ${ }^{183}$ why the sale of skin-bleaching products is a multi-million dollar industry within the United States, ${ }^{184}$ and why there is an earnings gap between lighterand darker-skinned Blacks. ${ }^{185}$ When considered in historical context, these social facts strongly suggest that colorism remains a real issue, and one which requires recognition by United States courts.

\section{COLOR IN CONTEMPORARY LAW}

As Part II demonstrates, color has historically played an important role in determining the social, political, and economic status of Black Americans. Unfortunately, analysis of the case law reveals that while colorism continues to operate in the United States, courts are confused about how to handle color discrimination claims. Not surprisingly, the resulting case law contains incomplete analyses and inconsistent outcomes. That law is, therefore, of limited utility to anyone desiring to engage seriously the question of color. This Part clarifies this area of the law. Section A probes the statutory basis for color claims. Section B examines the substantive content of those claims. Section $\mathrm{C}$ explores the increasing legal significance of color in light of shifting understandings of race and the growing presence of persons claiming mixed-racial ancestry. Finally, Section D analyzes the ways in which colorism may impede contemporary efforts to eliminate discrimination.

182. See Russell ET AL., supra note 2, at 38 (suggesting that Willie Horton, a Black Massachusetts criminal with a darker skin tone, may have been chosen for the TV ads that were part of George Bush's presidential campaign because of the suspicion that dark-skinned Blacks are more criminally dangerous); Dennis Love, Black and White: Walking a Fine Line, What Does "Racism" Mean? And Can We Live With It in our Midst?, ARIZ. RePUBLIC, Nov. 25, 1990, at E1 (noting that many perceived George Bush as playing on racial fears when he spotlighted Willie Horton in TV ads).

183. See supra note 174 and accompanying text.

184. See RUSSELl ET AL., supra note 2, at 51 (noting that in 1990, \$44 million worth of skinbleaching products were sold); America in Black and White: Shades of Prejudice (Nightline Transcript Broadcast, Feb. 28, 1997), available in 1997 WL 12826288 (noting that "skin bleach, sold almost exclusively to black women, is still a $\$ 44$ million a year industry").

185. See Hughes \& Hertel, supra note 10, at 1109; Keith \& Herring, supra note 10, at 777. 


\section{A. Statutory Support for Color Claims}

Courts have examined the question of color most extensively in the area of employment discrimination law. ${ }^{186}$ Title VII of the Civil Rights Act of 1964 and 42 U.S.C. $\S 1981$ of the Civil Rights Act of 1866 are of particular relevance. ${ }^{187}$ Title VII prohibits discrimination in employment on the basis of race, color, religion, sex, and national origin. ${ }^{188}$ Section 1981 provides, in part, that "[a]ll persons ... shall have the same right ... to make and enforce contracts ... as is enjoyed by white citizens." " ${ }^{\text {"S9 }}$ Section 1981 contains neither the word "race" nor the word "color." The Supreme Court has held, however, that $\S 1981$ affords a remedy against discrimination on the basis of race in both private and public employment. ${ }^{190}$

Courts should readily recognize color claims under Title VII given that the statute expressly includes color as a protected category. ${ }^{191}$ Absent strong evidence to negate this statutory

186. See Shah v. General Electric Co., No. C 83-0654-L, 1986 WL 8789, at *2 (W.D. Ky. Apr. 14, 1986) (recognizing color as a claim under $\$ 1981$ and Title VII); Abdulrahim v. Gene B. Glick Co., 612 F. Supp. 256, 264 (N.D. Ind. 1985) (finding a claim based upon skin color cognizable under § 1981); Felix v. Marquez, 24 Empl. Prac. Dec. (CCH) II 31,279 (D.D.C. 1980) (recognizing a color claim in a case involving a Puerto Rican woman because in Puerto Rico, there are "a mixture of races and ancestral origins"); Ali v. National Bank of Pak., 508 F. Supp. 611, 614 (S.D.N.Y. 1981) (dismissing a claim brought by a lighter-skinned Pakistani alleging discrimination in favor of a darker-skinned Pakistanis where the evidence was insufficient to establish that Pakistanis, based upon their national racial history, should be divided into "protected classes" according to color). For a brief overview of intraracial colorism cases, see generally Turner, supra note 4.

187. 42 U.S.C. § 2000e (1994) ("Title VII"); 42 U.S.C. § 1981 (1994).

188. See 42 U.S.C. $\$ 2000$ e(2) (1994). The Fifteenth Amendment to the U.S. Constitution also prohibits the denial of a citizen's right to vote on account of "race, color, or previous condition of servitude." U.S. CONST. amend. XV. Similar prohibitions have appeared in other federal laws and Executive Orders enacted to protect individual civil rights. See, e.g., Unemployment Relief Act of 1933, ch. 17, § 1, 48 Stat. 22 (1933) (formerly codified at 16 U.S.C. §§ 585-586); The National Industrial Recovery Act, ch. 90, 48 Stat. 195 (1933) (formerly codified at 15 U.S.C. $\S \S$ 701, 702); Exec. Order No. 8587, 5 Fed. Reg. 4445 (1940); Exec. Order No. 8802, 6 Fed. Reg. 3109 (1941); Exec. Order No. 9346, 8 Fed. Reg. 7183 (1943); Exec. Order No. 10308, 16 Fed. Reg. 12303 (1951); Exec. Order No. 10479, 18 Fed. Reg. 4899 (1953); Exec. Order No. 10925, 26 Fed. Reg. 1977 (1961); Exec. Order No. 11141, 29 Fed. Reg. 2477 (1964); Exec. Order No. 11246, 30 Fed. Reg. 12319 (1965); and Exec. Order No. 11375, 32 Fed. Reg. 14303 (1967). Unfortunately, none of these enactments define the term "color."

189. 42 U.S.C. $\$ 1981$ (1994).

190. See Johnson v. Railway Express Agency, 421 U.S. 454, 459-60 (1975). Although § 1981 does not include the word "race," the Supreme Court has construed it to forbid all racial discrimination in the making of private as well as public contracts. See Runyon v. McCrary, 427 U.S. 160, 174 (1976) (holding that $\S 1981$ provides a cause of action to private-sector employees on the grounds of racial discrimination in employment).

191. For this reason, most courts to address the issue have allowed color claims to proceed under Title VII. See Ali v. National Bank of Pak., 508 F. Supp. 611, 613 (S.D.N.Y. 1981) (noting 
language, ${ }^{192}$ a textual approach to statutory interpretation favors recognition of these claims. ${ }^{193}$ This conclusion is buttressed by evidence in Title VII's legislative history suggesting that Congress intended to provide protection against "shade" discrimination. ${ }^{19}$

Although $\S 1981$ does not use the word "color,",195 the 1866 Act does reference "white citizens." Use of this color-coded terminology

that "the literal language of the statute which prohibits discrimination on the basis of color would seem to apply to Ali's claim"); Felix v. Marquez, 24 Empl. Prac. Dec. (CCH) II 31, 279 (D.D.C. 1980) (noting in passing that discrimination on account of color is expressly forbidden by Title VII). But see Brown v. EEOC, No. 83-2531, 1984 WL 1003, at *3 (S.D.N.Y. Oct. 11, 1984) (rejecting without explanation an apparent claim based upon skin color).

192. Congress did not define "color" in Title VII. The Equal Employment Opportunity Commission ("EEOC"), the federal agency charged with administering Title VII, also has not defined the term "color" in its interpretive guidelines or regulations.

193. See United States v. Wells, 519 U.S. 482,497 (1997) (“[A]bsent a clearly expressed legislative intention to the contrary, [statutory] language must be regarded as conclusive.") (quoting Consumer Prod. Safety Comm'n v. GTE Pa., Inc., 447 U.S. 102, 108 (1980)).

194. See 110 CONG. REC. H-2552-55 (daily ed. Feb. 8, 1964), reprinted in U.S. EEOC, Legislative History of Titles VII and XI of Civil Rights Act of 1964, at 3193-94. Before Title VII's enactment, the following exchange occurred between Representatives Celler and Abernethy:

Mr. Abernethy. I will ask another question. If it should be illegal - and I understand it would be under this bill - for an employer not to hire a person on the ground of race - that is, color - would it be illegal not to hire because of the shade of color, that is because the skin of the applicant is too dark?

Mr. Celler. I suppose shade of color would be color. The whole embraces all its parts.

[Mr. Abernethy proceeds to detail reports of intraracial colorism in the Black community]

Mr. Abernethy: ... Would the FEPC have authority to correct an employment discrimination among our Negro citizens in the District of Columbia, where lightskinned Negroes refuse to hire Negroes of Dark skin?

Mr. Celler: . . I may say if there is any discrimination against the Negro regardless of his shade or gradation of pigmentation of his skin in employment, that discrimination would be a violation of this act.

Id.

195. For this reason, courts have been more reluctant to recognize color claims under $\S 1981$ than under Title VII. See, e.g., Sere v. Board of Trustees, 628 F. Supp. 1543, 1546 (N.D. Ill. 1986), aff'd, 852 F.2d 285 (7th Cir. 1988) (stating that color claims are not available under $\S$ 1981); Waller v. International Harvester Co., 578 F. Supp. 309, 314 (N.D. Ill. 1984) (same). Sere is particularly noteworthy. In that case, the plaintiff, a Black Nigerian, alleged that his supervisor refused to renew his contract and replaced him with a less qualified person. Both the supervisor and the replacement were Black Americans with lighter skin pigmentation. The plaintiff sued under Title VII and $\S 1981$, alleging race and national origin discrimination. In refusing to recognize the claim, the court noted that the plaintiff was "unable to offer any authority for the novel proposition that such discrimination may form the basis of a cause of action under section 1981.” Sere, 628 F. Supp. at 1546.

The court dismissed the national origin claim under $\S 1981$ because $\S 1981$ does not provide a remedy for discrimination on the basis of national origin. See id. The court, however, allowed the national origin claim under Title VII to proceed. Although it is not entirely clear from the opinion, it appears that the plaintiff did not allege race or color discrimination under Title 
implies that the statute extends to color claims. ${ }^{196}$ This language also demonstrates the convertibility of race and color to the enacting Congress. In addition, other important texts adopted during the same time period (e.g., the Fifteenth Amendment ${ }^{197}$ ) explicitly reference color separately from race. This again suggests that at the time $\S 1981$ was enacted, race and color were viewed as overlapping, but nonetheless distinct, phenomena.

The Supreme Court has stated that the phrase "as enjoyed by white citizens" clarifies Congress's concern with the racial character of the rights protected under $\S 1981,{ }^{198}$ but it has never directly addressed the issue of color. The Court therefore has not excluded color from $\S 1981$ 's protective ambit. Again, the language of $\S 1981$ suggests that this outcome would be incorrect. Moreover, as the Supreme Court has noted, "[w]hen terms used in a statute are undefined, we give them their ordinary meaning." refer to both a racial category and to skin color. ${ }^{200}$

VII. It is unclear whether the court's opinion on the merits of the race claim would have changed had the plaintiff made these additional arguments given the court's unwillingness to delve into the business of measuring skin colors.

196. See Abdulrahim v. Gene B. Glick Co., 612 F. Supp. 256, 263 (N.D. Ind. 1985) (observing that the statutory language of $\S 1981$ speaks in color terms).

197. U.S. CONST. amend. XV; see also infra note 207 (placing $§ 1981$ within the context of the Reconstruction Amendments).

198. See 42 U.S.C. $\$ 1981$ (1994); see also McDonald v. Santa Fe, 427 U.S. 273, 285-96 (1976) (reviewing the legislative history of $\S 1981$ and concluding that Congress intended to protect individuals of all racial groups); Georgia v. Rachel, 384 U.S. 780, 791 (1966) (stating that the phrase "as is enjoyed by White citizens" was added by the House to "emphasize the racial character of the rights being protected").

199. Asgrow Seed Co. v. Winterboer, 513 U.S. 179, 187 (1995) ("When terms used in a statute are undefined, we give them their ordinary meaning."); see also In re Tarvis, 53 F.3d 416, 419 (1st Cir. 1995) ("If possible, a statute should be construed in a way that conforms to the plain meaning of its text."); United States v. McLymont, 45 F.3d 400, 401 (11th Cir. 1995) ("[T]he plain meaning of the statute controls unless the language is ambiguous or leads to absurd results.").

200. "White" can be used as either an adjective or as a noun. The Oxford English Dictionary defines the noun form of the word "white" as "[a] white man; a person of a race distinguished by light complexion.” 20 OXFORD ENGLISH DICTIONARY 262 (2d ed. 1989) The dictionary offers the following examples of usage for 1833 and 1974, respectively: "The poor whites at the South are not as well off in their physical condition as the slaves, and hardly as respectable" and "Jim Prideaux was a poor white of the teaching community." Id.

When used as an adjective, Oxford's defines "white" as "[o]f the colour of snow or milk; having that color produced by reflection, transmission, or emission of all kinds of light in the proportion in which they exist in the complete visible spectrum, without sensible absorption, being thus fully luminous and devoid of any distinctive hue." $I d$. at 263 . The dictionary offers as an example of usage from 1833, Tennyson's "The lanes ... were white with may." Id. As an example of the most recent usage of the adjectival form, the dictionary offers "A round white moon that flooded the night with silver." Id. 
The legislative history of $\S 1981$ lends additional support to the conclusion that $\S 1981$ provides a remedy for color as well as race discrimination. When originally proposed in Congress, § 1981 included specific language prohibiting discrimination on the basis of race and color. Initial versions of the bill stated, in part: "there shall be no discrimination in civil rights or immunities among the inhabitants of any state or Territory of the United States on account of race, color, or previous condition of slavery .... ${ }^{201}$ Although the House ultimately struck this language from the statute, the debates make clear that the provision was removed because of the breadth of the terms "civil rights and immunities" and not because of a desire to exclude protection on the basis of race or color. ${ }^{202}$ Just as the omission of the word "race" from the statute does not preclude bringing race claims under $\S 1981$, the omission of the word "color" should not preclude the bringing of color claims. ${ }^{203}$

Finally, even if one concludes that Congress used the word "white" only to reference a racial category, this fact alone should not prevent the inclusion of color claims under $\S 1981$, given that color now plays a role analogous to the one that race played for the drafters. As Professor William Eskridge has argued, statutory texts are not static. $^{204}$ Their meanings are not fixed at the moment of enactment.

201. 36 CONG. Globe, 39th Cong., 1st sess. 211 (1866).

202. See Alexander M. Bickel, The Original Understanding and the Segregation Decision, 69 HARV. L. REV. 1, 11-29 (1955).

203. For cases permitting color claims under $\S 1981$, see Shah v. General Electric Co., No. C 83-0654 (CCB), 1986 WL 8789, at *1 (W.D. Ky. Apr. 14, 1986), rev'd on other grounds, 816 F.2d 264 (6th Cir. 1987) (holding that a dark-skinned person of Indian origin can proceed under $\S$ 1981 if the person can establish that race or color was a factor in the discrimination); Abdulrahim v. Gene B. Glick Co., 612 F. Supp. 256, 263 (N.D. Ind. 1985) (noting that a color claim could proceed under $\S 1981$ even if the race claim is dismissed); Vigil v. City of Denver, $15 \mathrm{Empl}$. Prac. Dec. (CCH) II 8000 (D. Colo. 1977) (ruling that Mexican-Americans may bring a cause of action under $\S 1981$ for discrimination on basis of skin color as opposed to national origin).

204. See William N. Eskridge, Jr., Dynamic Statutory Interpretation, 135 U. PA. L. REV. $1479,1482-83$ (1987) (setting forth and defending the theory that statutory interpretation need not be limited to discerning the intent of the legislature or the original purpose of the statute, but rather should consider subsequent interpretations of the text and current societal facts). Professor Eskridge notes:

[G]aps and ambiguities exist in all statutes, typically concerning matters as to which there was little legislative deliberation and, hence, no clear intent. As society changes, adapts to the statute, and generates new variations of the problem which gave rise to the statute, the unanticipated gaps and ambiguities proliferate. In such circumstances, it seems sensible that "the quest is not properly for the sense originally intended by the statute, [or] for the sense sought originally to be put into it, but rather for the sense which can be quarried out of it in the light of the new situation." Moreover, as time passes, the legal and constitutional context of the statute may change. Should 
Rather, statutes must be interpreted dynamically, in light of their present as well as their historical contexts ${ }^{205}$ especially when the statute at issue is old and written in general terms. ${ }^{206}$ Because colorism involves many of the same stereotypes and assumptions that result in discrimination on the basis of race, it provokes the same sort of invidious treatment that Congress sought to eliminate in 1866 when $\S$ 1981 was enacted. ${ }^{207}$ The mere fact that the trigger for discrimination is skin color and not race should not bar coverage of these claims under $§ 1981$.

Setting aside narrow questions of statutory interpretation, some observers may raise more general policy objections to legal recognition of claims based on skin color. These observers will question whether skin color is different from any number of other legally permissible factors upon which people make distinctions (e.g., eye color, hair color, height, etc.), and will assert that recognition of discrimination on the basis of skin color will, in effect, spark a downward movement on the proverbial slippery slope. ${ }^{208}$ It seems to me that the most compelling difference between skin color and these other factors is the pervasive and well-documented history of discrimination on the basis of skin color in this country. This historical practice was of sufficient magnitude and consistency that the word "color" was explicitly included, separately from the word "race," in both the Fif-

not an interpreter "ask [her]self not only what the legislation means abstractly, or even on the basis of legislative history, but also what it ought to mean in terms of the needs and goals of our present day society[?]"

Id. at 1480 (internal citations omitted). For further development of Professor Eskridge's theory, see generally WILLIAM N. ESKRIDGE, JR., DYNAMIC STATUTORY INTERPRETATION (1994).

205. See Eskridge, supra note 204, at 1484-96 (using the text of $\S 1983$ and Title VII to illustrate this point).

206. See id. at 1481 .

207. Section 1981 was part of a series of civil rights statutes enacted by Congress during the Reconstruction era in order to advance the goals of the newly ratified Thirteenth, Fourteenth, and Fifteenth Amendments. See Michael Reiss, Requiem for an "Independent Remedy": The Civil Rights Acts of 1866 and 1871 as Remedies for Employment Discrimination, 50 S. CAL. L. REV. 961, 963, 983 (1977). When originally enacted, the statutory provision was designed to protect former slaves against encroachments on their civil rights. See id.

208. One response to this concern is to argue that antidiscrimination law is based on sound reasoning and that it is simply irrational to deprive an individual of employment, housing, or other societal benefits based upon something as arbitrary and immutable as skin color. The problem with this argument is that distinctions based on eye color, hair color, and height may also be irrational to the extent that those qualities are unrelated to the employment or other opportunity in question. In addition, setting aside for the moment devices like colored contact lenses, hair dyes, and platform shoes, eye color, hair color, and height are also immutable. Thus, arguments for prohibiting discrimination on the basis of skin color must rest upon some other basis. 
teenth Amendment to the Constitution and in Title VII of the Civil Rights Act of 1964. In addition, skin color (like race) has been and continues to be used as a basis for identifying underrepresented discrete and insular minorities within racial classifications. ${ }^{209}$ Skin color also provokes many of the same invidious stereotypes and behaviors that the law seeks to proscribe regarding race. For these reasons, discrimination on the basis of skin color is more like discrimination on the basis of race than discrimination on the basis of eye color, hair color, or height. Therefore, like race, discrimination on the basis of skin color merits protection.

\section{B. Substantive Content of Color Claims}

Because Title VII and $\S 1981$ should be read to cover color claims, the primary focus must shift to determining with greater precision the substantive content of these claims. Of course, the most straightforward approach to this question is to conclude that color is equivalent to race or is a proxy for national origin or some other protected classification. Not surprisingly, litigants and the courts have often treated color synonymously with race without attempting to determine if and where these claims differ. ${ }^{210}$ Porter v. Illinois

209. Following footnote four of United States v. Carolene Products Co., 304 U.S. 144, 153 n.4 (1938) (suggesting that courts should examine legislation affecting "discrete and insular minorities" more carefully than other types of legislation because prejudice against these groups may "tend[] seriously to curtail the operation of those political processes ordinarily to be relied upon to protect minorities"), the Supreme Court has consistently applied a heightened level of judicial scrutiny to racial classifications under the Equal Protection Clause of the Fourteenth Amendment. Although the analysis set forth here does not examine color claims under the Equal Protection Clause, because the motivations behind colorism and racism are so similar, there is no obvious reason why the same searching judicial scrutiny should not apply to color claims.

210. See, e.g., Fernandes v. Costa Bros. Masonry, 199 F.3d 572, 579-81 (1st Cir. 1999) (treating, without explanation, claims alleging race and color discrimination as race claims); Love v. United Airlines, No. 98 C 6100, 1999 U.S. Dist. LEXIS 4069, at*7-*8 (N.D. Ill. Mar. 25, 1999) (discussing allegations of race and color discrimination merely as race discrimination); Dean v. New York Marriott Fin. Ctr. Hotel, No. 94 Civ.4343 (TPS), 1998 U.S. Dist. LEXIS 13957, at *7 (S.D.N.Y. Sept. 4, 1998) (noting the plaintiff's claims of discrimination on the basis of race, color, and national origin, and then discussing only race discrimination under Title VII). The tendency to conflate race and color or to merely see color as nothing more than an indicator of race is apparent in several prominent opinions. See, e.g., Shaw v. Reno, 509 U.S. 630, 647 (1993) (observing that black voters have "little in common with one another but the color of their skin"); McDonald v. Santa Fe, 427 U.S. 273, 284 (1976) (defining race discrimination as retaining "employees of one color while discharging those of another color"); Hopwood v. Texas, 78 F.3d 932, 957 (5th Cir. 1996) (noting that the University of Texas engaged in unlawful race discrimination by treating applicants differently based upon the color of their skin). 
Department of Children and Family Services ${ }^{211}$ illustrates this point. The plaintiff, a light-skinned Black male, filed a claim under Title $\mathrm{VII}^{212}$ alleging discrimination on the basis of both race and color. Neither the plaintiff nor the court made any attempt to distinguish between the two forms of discrimination. Rather, they both used the terms interchangeably. ${ }^{213}$

This approach is defensible if one accepts that race and color sometimes overlap. The problem, however, is that this approach renders color claims superfluous or void of independent meaning. Color discrimination becomes nothing more than race discrimination or national origin discrimination. This makes little sense in the Title VII context given the language of the statute. As one court has aptly noted:

[Because] the statutes and case law repeatedly and distinctly refer to race and color [t]his court is left with no choice but to conclude, when Congress and the Supreme Court refer to race and color in the same phrase, that "race" is to mean "race", and "color" is to mean "color". To hold otherwise would mean that Congress and the Supreme Court have either mistakenly or purposefully overlooked an obvious redundancy. ${ }^{214}$

If a color claim is not solely a proxy for some other form of discrimination, then what exactly does it encompass? Analysis of the case law reveals that, although courts have considered whether color claims are separately cognizable under Title VII and $\S 1981$, few have afforded this question much attention in their written opinions. Most courts merely state that color claims either are or are not permitted without offering any explanation for their conclusions, and without delving too deeply into what makes a color claim analytically distinct. $^{215}$

211. No. 98-1158, 1998 WL 847099 (7th Cir. Oct. 29, 1998).

212. The plaintiff also brought claims under the Age Discrimination in Employment Act, Pub. L. No. 96-170, 93 Stat. 1284 (codified at 42 U.S.C. $§ 1983$ (1994)). See Porter, 1998 WL 847099 , at $* 1$.

213. See id.; see also Martin v. Georgia-Pacific Corp., 568 F.2d 58, 60 (8th Cir. 1977) (failing to make any distinctions between Title VII discrimination claims based on race and color); Logan v. General Fireproofing Co., 521 F.2d 881, 883 (4th Cir. 1971) ("On this issue, the record includes no direct evidence that would identify any Negro who had been specifically denied employment because of his race or color.") (emphasis added).

214. Walker v. Internal Revenue Serv., 713 F. Supp. 403, 406 (N.D. Ga. 1989) (emphasis added).

215. See supra notes 186,195 and accompanying text. 
Walker v. Internal Revenue Service ${ }^{216}$ is a notable exception. In Walker, the United States District Court for the Northern District of Georgia held that an allegation of discrimination based on skin color states a cognizable claim under Title VII. ${ }^{217}$ There, a light-skinned Black employee alleged that her supervisor, a dark-skinned Black, discriminated against her because of her lighter skin tone. ${ }^{218}$ The court concluded that the plaintiff's claim was not barred because the plaintiff and her supervisor were of the same race. The court observed that, after the United States Supreme Court's 1987 decision in Saint Francis College v. Al-Khazraji, ${ }^{219}$ "it is not even required that a victim of discrimination be of a distinctive physiognomical sub-grouping [from the perpetrator of the discrimination]." ${ }^{220}$ Thus, the court was

216. 713 F. Supp. 403 (N.D. Ga. 1989).

217. The court rejected the plaintiff's claims under $\S 1981$ because $\S 1981$ does not encompass employment discrimination claims brought by federal employees. See id. at 409. In analyzing color claims under Title VII, the court nonetheless relies upon cases interpreting § 1981 and does not appear to recognize a distinction between the two statutory provisions. Thus, it appears that the court would extend its analysis to $\S 1981$ in cases involving private employees. Indeed, the court explicitly states that "in a suit such as this, the legal elements and the facts necessary to support a claim for relief under Title VII are identical to the facts which support a claim under Section 1981." Id. at 405. In a subsequent opinion, the court rejected the plaintiff's claims on the merits. See Walker v. Internal Revenue Serv., 742 F. Supp. 670, 675-76 (N.D. Ga. 1990).

218. See Walker, 742 F. Supp. at 670.

219. 481 U.S. 604 (1987). In Saint Francis, the Court rejected the defendant's argument that $\S 1981$ does not cover claims of discrimination by one Caucasian against another and held that in order to bring a claim under $\S 1981$, the plaintiff need not necessarily be of a different race from the defendant under contemporary scientific theory. The court noted that $\S 1981$, "“at a minimum,' reaches discrimination against an individual because he or she is genetically part of an ethnically and physiognomically distinctive sub-grouping of homo sapiens." Id. at 613. However, the Court also made clear that "a distinctive physiognomy is not essential to qualify for section 1981 protection." Id. Rather, the Court noted that "Congress intended to protect from discrimination identifiable classes of persons who are subjected to intentional discrimination solely because of their ancestry or ethnic characteristics." Id. Thus, even if the plaintiff and defendant are not physiognomically distinctive, the plaintiff can still bring a race claim if she can show that the defendant acted on the basis of her ancestry or ethnicity because both ancestry and ethnicity were bases for claims under $\S 1981$ at the time the statute was adopted.

220. Id. The Walker opinion is confusing concerning the relationship between skin color and physiognomy and whether individuals of different skin tones are physiognomically distinct. The court defines "physiognomic" as "relating to physiognomy or "external aspect." Walker, $713 \mathrm{~F}$. Supp. at 406. Webster's defines "physiognomy" as "the art of appraising character or personality from facial features" or "outward appearance and character of an abstract or inanimate entity." WEBSTER's, supra note 42, at 887. If one interprets the word generally to mean relating to external physical appearance, then one could argue that skin color is a physiognomical difference. On the one hand, the Walker court acknowledges this fact when it states: "a person's color is closely tied to his ancestry and could result in his being perceived as a 'physiognomically distinctive sub-grouping of homo sapiens.'” Walker, 713 F. Supp. at 406. Yet, immediately following this statement, the court notes: "Notwithstanding that proposition, it is not even required that a victim of discrimination be of a distinctive physiognomical subgrouping, a particularly relevant fact to the case at hand." Id. Later in the opinion, the court observes that subgroups 
willing to recognize a color discrimination claim under Title VII when the plaintiff and the defendant were of the same race. ${ }^{221}$

In allowing the action to proceed, the court also rejected the defendant's assertion that "color" has generally been interpreted to mean the same thing as "race." 222 The court stated that both the statute and case law "repeatedly and distinctly refer to race and color.",223 In attempting to distinguish color claims from race claims, the court explained that, in some situations, the most practical way to bring a Title VII suit may be on the basis of color as opposed to race. Unfortunately, it is not completely clear what the court meant by this language. Dissecting the opinion carefully, it appears that the court believed: (1) there are differences among individuals within racial categories and discrimination may occur on the basis of these differences; and (2) the mixture of races and ancestral national origins may complicate the analysis by making it impossible to delineate racial categories or to determine who fits within what racial group. In making the first point, the court turned again to Saint Francis and relied upon the Supreme Court's observation that Congress intended $\S 1981$ to apply to discrimination against sub-groups within the Caucasian race, including Finns, gypsies, Basques, Hebrews, Swedes, Norwegians, Germans, Greeks, Italians, Spaniards, Mongolians, Russians, Hungarians, Irish, and French. ${ }^{224}$ The court thus concluded that if

exist within racial categories on the basis of color and physical characteristics and suggests that discrimination may occur on the basis of these factors. See id. at 407-08. Yet, in the very next paragraph, the court notes, "the Supreme Court has said that a 'distinctive physiognomy is not essential to qualify for section 1981 protection.' It is therefore not controlling that in the instant case a black person is suing a black person." Id. at 408 (quoting Saint Francis, 481 U.S. at 605). Even if the court were to maintain consistently that the plaintiff and the defendant were physiognomically distinct because of their different skin tones, the court would still need to explain why that difference should provide the basis for a cause of action based on skin color under Title VII and $\S 1981$ (e.g., how does skin color differ from race, or hair color, for that matter). Unfortunately, the court fails to undertake this task.

221. The language in Walker is questionable (and technically dicta) to the extent that it suggests that Saint Francis supports the proposition that color claims are cognizable under $\S 1981$. Although Saint Francis holds that individuals of the same race are not precluded from bringing race claims on the basis of ancestry or ethnicity, Saint Francis does not say that individuals of the same race may bring claims on the basis of skin color. Thus, while Saint Francis may be used to support the proposition that membership in the same racial group does not prevent the bringing of a race discrimination claim, it does not directly support the separate proposition that color is a claim that is cognizable under $\S 1981$. For further development of this point, see Sandi J. Robson, Intra-Racial, Color-Based Discrimination and the Need for Theoretical Consistency after Walker v. Internal Revenue Service, 35 VILL. L. REV. 983, 993-96 (1990).

222. See Walker, 742 F. Supp. at 670-71.

223. Walker, 713 F. Supp. at 406 (emphasis added).

224. See St. Francis College v. Al-Khazraji, 481 U.S. 604, 612 (1987). 
Congress intended to protect sub-groups within the Caucasian race, it would be anomalous to believe that it did not intend to protect subgroups within the Black race. The court observed: "It would take an ethnocentric and naive world view to suggest that we can divide Caucasians into many subgroups but somehow all Blacks are part of the same subgroup. There are sharp and distinctive contrasts amongst native Black African peoples (sub-Saharan) both in color and in physical characteristics." ${ }^{225}$

Walker is critically important because it is the first case in which a court recognized that Title VII provides a remedy for intraracial color discrimination. In addition, the opinion offers the most detailed judicial analysis of skin color discrimination to date. Indeed, other courts have shown a greater willingness to recognize color discrimination claims under Title VII after Walker. ${ }^{226}$ As I explain below, however, the Walker court's analysis is incomplete. For the moment, I shall focus on the court's observation that discrimination may occur on the basis of differences within racial groups. I shall return to the complexities raised by mixed racial heritage in Section III.C.

As an initial matter, the court in Walker is correct in concluding that the mere fact that a plaintiff and defendant are of the same race should not legally bar the bringing of an intraracial color claim. ${ }^{227}$ As Saint Francis makes clear, it is not legally impossible for a Black plaintiff to prove that she was the victim of discrimination by a Black defendant.

The more subtle question raised by Walker concerns whether there should be a factual presumption that a Black defendant did not discriminate because the plaintiff is also Black. Such a presumption is insupportable. It is well-documented that individuals within protected classifications are not immune from the forces of socialization at work in the larger society. ${ }^{228}$ These persons may incorporate the dominant

225. Walker, 713 F. Supp. at 407-08.

226. See, e.g., Hansborough v. City of Elkhart Parks and Recreation Dept., 802 F. Supp. 199, 206 (N.D. Ind. 1992); Sanders v. University of the District of Columbia, No. 88-3614 SS, 1991 U.S. Dist. LEXIS 7448, *2-*3 (D.D.C. June 4, 1991).

227. See supra note 221 for a critique of the Walker court's over-reliance upon Saint Francis. Saint Francis does not establish that color claims are cognizable under $\S 1981$. To reach this conclusion, one must rely upon other arguments. See supra notes 195-209 and accompanying text.

228. For instance, within the Black community, associations like the Brown Fellowship Society refused to accept slaves and dark-skinned free people as members. See IRA BERLIN, Many Thousands Gone: The First Two Centuries of Slavery in North AMERICA 324 (1998). The dark-skinned community, in turn, created similar associations, like the Humane 
society's views and may very well unconsciously act upon those views in ways that are harmful to members of their own groups. Thus, women discriminate against women (e.g., on the basis of race). Men also discriminate against men (e.g., on the basis of masculinity or femininity). And, as the historical overview in Part II demonstrates, Blacks discriminate against Blacks (e.g., on the basis of skin color). As we know, some free mulattoes owned slaves $;{ }^{229}$ some light-skinned slaves believed they were intellectually and socially superior to darker slaves; ${ }^{230}$ and some light-skinned persons, favored by the White majority, expressed hostility towards their darker-skinned Black brethren and sought to disassociate themselves from darker Blacks in order to protect their favored status. ${ }^{231}$ Although conventional analysis relying upon cases in other factual contexts could have been employed in Walker to destroy any factual presumption that discrimination does not occur between individuals of the same race, an understanding of colorism assists in this effort by explaining how such discrimination may occur between Blacks of varying skin tones. In short, it encourages courts to look beyond the broad category of race and to investigate the ways in which more subtle forms of discrimination occur.

Unfortunately for analytical purposes, the Walker opinion dealt only with intraracial color discrimination. The case involved a member of one race discriminating against a member of the same race on the basis of skin color. ${ }^{232}$ Because of this factual context, the court had no cause to examine the question of interracial color discrimination (a case where members of one race distinguish between members of a different race on the basis of skin color). Yet as Part II illustrates, interracial color discrimination exists. The question thus arises: should courts treat interracial claims differently from intraracial claims? Should the fact that a White person awards benefits to a light-skinned Black individual create a factual presumption that she has not discriminated against a darker-skinned Black person? As I explain below, the answer is no.

Fundamentally, interracial claims are no different from intraracial claims. As with intraracial claims, courts must not overlook inter-

\footnotetext{
Brotherhood. See id. ("Thus did the color divisions that supported slavery become suffused throughout the black community: what whites did to browns, browns would do to blacks.").

229. See supra note 79 and accompanying text.

230. See supra notes 94-96 and accompanying text.

231. By the same token, darker-skinned Blacks have at times shunned their lighter-skinned counterparts. See supra notes 139-44, 150-52, and accompanying text.

232. See Walker v. Internal Revenue Serv., 713 F. Supp. 403, 403 (N.D. Ga. 1989).
} 
racial discrimination by proceeding blithely on the assumption that a White person cannot be racist if she awards benefits to someone within the same race as the plaintiff. We can readily comprehend the fallacy of this assumption when we acknowledge that a White person might distinguish between a Black person who has recently emigrated from Haiti and harbors an accompanying accent, and a Black person who was born in the United States. In that situation, national origin supplies the basis for the intragroup comparison. ${ }^{233}$ Color operates in a similar fashion: lighter skin color, like the absence of a foreign accent, brings the person receiving favorable treatment closer to the preferred ideal-with skin color, that ideal is whiteness. Again, the central point is that one cannot allow a focus on broad racial categories to obscure the fact that racial groups are not monolithic and that nuanced forms of intragroup discrimination, like colorism, exist.

Finally, Walker fails to articulate clearly the essence of a color claim and how it differs from a race claim. The key point that needs to be understood is that colorism and racism are distinct phenomena that sometime overlap. At times, racism will occur regardless of a person's color. Thus, a person whose skin is White, but whose ancestors are known to be Black, may be classified as Black and subject to racist acts on that basis. At times, colorism will operate independently of race. Thus, two individuals within the same racial classification may be subject to different treatment because of their varying skin tones. In that situation, the basis for distinction is not their placement in a particular racial category but rather their color within that category. Of course, the meaning afforded color may result from racist beliefs; that is to say, being light or dark may have meaning because being light or dark is associated with being of or closer to a certain racial ideal (i.e., White). However, the meaning afforded color may result from factors unrelated to racist beliefs. Colorism may stem from historically based assumptions about the correlation between color and socioeconomic class, color and beauty, color and intellect, or color and criminality, among other things. Finally, at times colorism and racism will overlap; that is, a person will be treated differently because

233. A similar differentiation occurs when a White person says to her Black friend, "Oh, you're not really Black," or, "I don't think of you as Black." These supposedly complimentary statements evidence a clear demarcation in the mind of the speaker between the status of the individual being addressed versus the status of Blacks generally. These comments do nothing to challenge the stereotypical assumptions of Blackness held by the speaker. The category of Black remains something outside the norm, something less than desirable. The only difference is that the individual being addressed is exempted from categorization within that group. 
of assumptions about both her race and her color. Thus, a Black woman with chocolate brown skin may be subject to both racism and colorism simultaneously.

In sum, although they sometimes overlap, color claims are analytically different from race claims. The separation of individuals into racial categories and subsequent discrimination on that basis is, in essence, racism. The negative treatment of individuals on the basis of skin color is colorism. The danger is that if courts focus solely on race, they may overlook discrimination based on skin color because it may be difficult to believe that a person who hires Blacks will engage in discrimination against other Blacks, or that a person who is Black would discriminate against another Black person. If, however, courts understand colorism, then they are more likely to perceive the intricate ways in which people discriminate even within racial categories.

\section{Race, Color, Mixed Racial Identity and Employment Discrimination Law}

My old man's a white old man

And my old mother's black.

If ever I cursed my white old man

I take my curses back.

If ever I cursed my black old mother

And wished she were in hell,

I'm sorry for that evil wish

And now I wish her well.

My old man died in a fine big house.

My ma died in a shack.

I wonder where I'm gonna die,

Being neither white nor black?

-Langston Hughes ${ }^{234}$

One of the more interesting aspects of current analyses of color is the suggestion that the presence of persons of mixed racial heritage or mixed ancestry may complicate matters in ways that render reliance upon race problematic but reliance upon color helpful. ${ }^{235}$ Sadly,

234. LAngston Hughes, Cross, in Selected Poems of LANGSTON Hughes 158 (1959).

235. See, e.g., Walker, 713 F. Supp. at 406-07 ("Discrimination against an individual because such individual comes from a racially mixed heritage possibly is of particular relevance to the instant case [based on color]."); Felix v. Marquez, 24 Empl. Prac. Dec. (CCH) If 31,279 at 31,279 (D.D.C. Sept. 11, 1980) ("Color may be a rare claim, because color is usually mixed with or sub- 
courts have made this observation in passing without further explanation or analysis. The argument, however, appears to be based on two insights: (1) the more the races mix, the more difficult it becomes to place individuals within specific racial categories; and (2) discrimination may nonetheless occur on the basis of skin color. These observations are of immense contemporary significance as the rate of interracial marriage increases, ${ }^{236}$ and as questions surface concerning what race is and who belongs in what racial category. ${ }^{237}$ If, as many argue, differentiating among racial groups is becoming more complicated, ${ }^{238}$ then it is important to consider both whether existing legal frameworks are in fact sufficient to redress claims brought by individuals who are neither visibly Black nor visibly White, and whether permitting claims based upon skin color will improve matters.

To conceptualize this analysis, assume that Alex, who is Black, produces a child with Beth, who is White. The child, Carol, resembles

ordinated to claims of race discrimination, but considering the mixture of races and ancestral national origins in Puerto Rico, color may be the most practical claim to present.").

236. Since the Supreme Court held bans against interracial marriage unconstitutional in Loving v. Virginia, 388 U.S. 1 (1967), the number of interracial marriages in the United States has substantially increased. In 1970, there were 310,000 mixed-race couples. By 1992, there were 1,161,000 mixed-race couples. See Arlene F. Saluter, Marital Status and Living Arrangements, in U.S. DEPT. OF COMMERCE, CURRENT POPUlATION REPORTS, POPUlation CHARACTERISTICS X (1992). From 1980 to 1995, the rate of interracial marriage increased about $1 \%$, from $1.3 \%$ to $2.4 \%$. See Patricia J. Williams, Big words, small divisions, THE NATION, Aug. 25, 1997, at 9. Interestingly, the rate of exogamy for African-Americans is less than that of other racial groups. See SALUTER, supra, at XI (noting that, of all interracial married couples, the African-American/White intermarriage rate hovers at about $7 \%$, while the JapaneseAmerican/White intermarriage rate is $55 \%$ and the Chinese-American/White rate is $40 \%$ ). The number of Black-White unions have nonetheless steadily increased. In 1970, there were 65,000 Black-White couples. In 1992, this number had grown to 246,000 - a increase from $0.1 \%$ to $0.5 \%$ of all marriages. Between 1980 and 1990, Black-White intermarriage increased over 50\%. See id. at XI. For more information on trends in interracial marriage, see Ernest Porterfield, BlackAmerican Intermarriage in the United States, 5 MARRIAGE \& FAM. REV. 17 (1984); M. Belinda Tucker \& Claudia Mitchell-Keenan, New Trends in Black American Interracial Marriage: The Social Structural Context, 52 J. MARRIAGE \& FAM. 209 passim (1990); Steven A. Holmes, Study Finds Rising Number of Black-White Marriages, N.Y. TIMES, July 4, 1996, at A16.

237. See generally Luther Wright, Jr., Who's Black, Who's White, and Who Cares: Reconceputalizing the United States's Definition of Race and Racial Classifications, 48 VAND. L. REV. 513,513 (1995) (examining problems arising from the lack of a precise definition of race in the United States). Indeed, the problem is magnified when one considers the proliferation of racial groups within the United States. The presence of more racial categories and interracial sex among these groups has the potential to make racial identification even more complex.

238. See Michael Omi, Racial Identity and the State: The Dilemmas of Classification, 15 L. \& INEQ. J. 7, 18-19 (1997) (arguing that it is difficult to determine for which racial category each individual qualifies); see also Paul Knepper, Race, Racism and Crime Statistics, 24 S.U. L. REV. 71, 79 (1996) ("Skin color by itself [cannot] be used to identify ... groups, nor [can] national, religious, geographical, linguistic, or cultural differences."). 
Vanessa Williams: ${ }^{239}$ she is fair-skinned, with slightly curly brown hair, and hazel eyes. As Carol navigates the world, she may be viewed as either Black or White, as both Black and White, as neither Black nor White but something else, or as being of indeterminate racial ancestry. The purpose of this section is to examine, within the context of employment discrimination law, how discrimination against Carol could be conceptualized as race discrimination, color discrimination, or both, and to demonstrate how these analyses are related.

1. Analytical Frameworks Under Title VII and Section 1981. Courts have developed two analytical frameworks for individual ${ }^{240}$ employment discrimination claims under Title VII and $\S 1981:^{241}$

239. In 1983, Vanessa Williams became the first Black woman to be crowned Miss America. She was forced to abdicate her title in 1984 when it became known that Penthouse magazine was about to publish nude photos of Ms. Williams taken before her reign. Since that time, Ms. Williams has enjoyed a successful music career and starred in a number of motion pictures. See Fact File (visited Mar. 3, 2000) <http://www.allaboutvanessa.8m.com/factfile.html $>$ (on file with the Duke Law Journal).

240. Certain systemic claims are also available under Title VII and to a lesser extent under $\S$ 1981. Systemic claims come in two varieties: (1) pattern and practice actions; and (2) disparate impact cases. See, e.g., Teamsters v. United States, 431 U.S. 324 (1977) (illustrating a pattern and practice claim); Griggs v. Duke Power Co., 401 U.S. 424 (1971) (discussing a claim of disparate treatment). In a pattern or practice case, the plaintiff seeks to create an inference of unlawful intent by showing a statistically significant disparity between the defendant's workplace and an appropriate labor market. See Teamsters, 431 U.S. at 324, 331-32; Hazelwood Sch. Dist. v. United States, 433 U.S. 299, 299-300 (1977). Statistical comparisons are also employed in disparate impact claims. See, e.g., Dothard v. Rawlinson, 433 U.S. 321, 330 (1977). In disparate impact actions, plaintiffs attempt to show that a facially neutral criteria or policy has a significant adverse impact on a protected group that cannot be justified through business necessity. See Griggs, 401 U.S. at 424. Proof of unlawful intent is not required. See id. While $\$ 1981$ covers pattern or practice claims, it does not embrace disparate impact theory. See General Bldg. Contractors Ass'n v. Pennsylvania, 458 U.S. 375, 391 (1982) ("We conclude, therefore, that $§ 1981$. . can be violated only by purposeful discrimination.").

Although it is theoretically possible to bring a systemic claim on the basis of skin color (e.g., by establishing that a defendant has no or few employees with skin darker than a certain shade), as a practical matter it will be more difficult to show a statistically significant disparity between the defendant's labor force and the surrounding labor market on the basis of skin color. Although statistical evidence (from the census and other sources) is available regarding racial differences within population groups, such data are not kept regarding skin color differences. This absence may explain, in part, why there are no such systemic cases to date.

241. Although the scope of coverage under Title VII and $\S 1981$ is different, and although the statutes have different administrative structures and remedies, see BARBARA LINDEMANN \& PAUl Grossman, EMPLOYMENT DisCRIMINATION LAW 921-29, 969-76 (3d ed. 1996), analysis under the two statutes is basically the same insofar as setting forth the substantive elements of a race-based claim of individual disparate treatment is concerned. See Walker v. Internal Revenue Serv., 713 F. Supp. 403, 405 (N.D. Ga. 1989) ("[I]n a suit such as this one, the legal elements and facts necessary to support a claim for relief under Title VII are identical to the facts which support a claim under $\S 1981$.”). 
direct evidence cases and inferential cases. In direct evidence cases, a plaintiff must come forth with (1) a "smoking gun," that is, direct evidence that the defendant acted on the basis of unlawful criteria, ${ }^{242}$ or (2) circumstantial evidence of sufficient quality to persuade the factfinder that the defendant, more likely than not, considered an unlawful factor when making the employment decision in question. ${ }^{243}$ If the plaintiff passes this threshold, the burden shifts to the defendant either to negate the plaintiff's contentions or to justify its action with an acceptable defense. ${ }^{244}$

Because direct evidence is rare, the majority of employment discrimination cases are proved inferentially. These cases follow the framework developed by the Supreme Court in McDonnell Douglas Corp. v. Green, ${ }^{245}$ Texas Department of Community Affairs v. Burdine, ${ }^{246}$ and St. Mary's Honor Center v. Hicks. ${ }^{247}$ Under this framework, to establish a prima facie case, the plaintiff must show that (1) she falls within a protected classification; (2) she applied and was qualified for the position in question; (3) she was denied the position notwithstanding her qualifications; and (4) the position remained open after her rejection and the employer continued to seek applica-

242. See, e.g., United Auto. Workers v. Johnson Controls, 499 U.S. 187, 197 (1991) (opining that a policy of excluding women capable of bearing children from jobs leading to lead exposure is facially discriminatory on the basis of gender); Trans World Airlines v. Thurston, 469 U.S. 111,124 (1985) (holding that a policy conditioning transfer rights on the age of airline captains is facially discriminatory and barred by the ADEA); Wilson v. Southwest Airlines, 517 F. Supp. 292, 304 (N.D. Tex. 1981) (finding that a policy excluding males from the position of flight attendant provides direct evidence of sex discrimination).

243. See, e.g., Tyler v. Bethlehem Steel Corp., 958 F.2d 1176, 1187 (2d Cir. 1992) ("[P]laintiff [must] submit enough evidence that, if believed, could reasonably allow a jury to conclude that the adverse employment consequences were 'because of' an impermissible factor."); Sennello v. Reserve Life Ins. Co., 872 F.2d 393, 394-95 (11th Cir. 1989) ("With [defendant's highly discriminatory] statements [about women] in the record, along with the facts surrounding her demotion and termination, no further inference would be required to conclude that [the defendant] discriminated against [the female plaintiff]."); Slack v. Havens, 522 F.2d 1091, 1095 (9th Cir. 1975) (quoting Aeronca Mfg. Co. v. NLRB, 385 F.2d 724, 728 (9th Cir. 1967)) ("[T]he trier of fact must make the necessary determination based upon 'reasonable inferences drawn from the totality of facts, the conglomerate of activities, and the entire web of circumstances presented by the evidence on the record as a whole."').

244. For example, the defendant might allege that it acted pursuant to a lawful affirmative action plan or on the basis of a bona fide occupational qualification. See, e.g., Johnson Controls, 499 U.S. at 206 (1991) (rejecting the employer's argument that a fetal protection policy was a bona fide occupational qualification); Johnson v. Transportation Agency, 480 U.S. 616, 641-42 (1987) (stating that an employer's preference for female employees was justified under an affirmative action policy).

245. 411 U.S. 792 (1973).

246. 450 U.S. $248(1981)$.

247. 509 U.S. $502(1993)$. 
tions from persons of plaintiff's qualifications. ${ }^{248}$ Usually, the fourth requirement is established by showing that the defendant hired someone outside of the plaintiff's protected category (i.e., someone of a different race). After establishing a prima facie case, the burden of production shifts to the defendant to come forth with a legitimate nondiscriminatory reason for the employment action. ${ }^{249}$ If he does, the plaintiff must prove that the proffered reason is a pretext and that unlawful discrimination motivated the defendant. ${ }^{250}$ In both direct

248. See McDonnell-Douglas, 411 U.S. at 802 . The elements of the prima facie case are flexible and may change depending upon the nature of the claim. See id. at 802 n.13. For example, in a situation where an older person is demoted or fired, the elements of the prima facie case may consist of a showing that the plaintiff (1) was within the age group protected under the Age Discrimination in Employment Act; (2) suffered an adverse employment action; (3) was performing her job at a level that met the employer's reasonable expectations at the time of the demotion; and (4) was replaced with someone younger. See, e.g., Greene v. Safeway Stores, 98 F.3d 554, 558 (10th Cir. 1996) (specifying the elements of prima facie case in an age discrimination case); Tuck v. Henkel Corp., 973 F.2d 371, 375 (4th Cir. 1992) (outlining the elements of the prima facie case in a situation involving a demotion); Stein v. National City Bank, 942 F.2d 1062, 1064-65 (6th Cir. 1991) (discussing the elements of a prima facie case where age discrimination is at issue).

249. See Burdine, 450 U.S. at 253 (citing McDonnell Douglas, 411 U.S. at 802).

250. See Hicks, 509 U.S. at 507. In Hicks, the Supreme Court is fairly clear in stating that the factfinder's rejection of the defendant's explanation of its conduct does not compel a judgment for the plaintiff. See id. at 511. Until recently, it remained unclear whether proof of pretext, combined with the elements of the prima facie case, would be sufficient for a plaintiff to recover or whether the plaintiff was also required to come forth with additional evidence of discrimination. $C f$. $i d$. (suggesting that proof of pretext may "permit the trier of fact to infer the ultimate fact of intentional discrimination"); id. at 515 (stating that "a reason cannot be proved to be "a pretext for discrimination' unless it is shown both that the reason was false, and that discrimination was the real reason") (quoting Burdine, 450 U.S. at 253)). Some courts interpreted this language in Hicks to allow a finding for the plaintiff based upon a showing of pretext only, while others required that the plaintiff offer more direct evidence of discrimination (i.e., a pretext-plus standard). See, e.g., Card v. Hercules, Inc., 5 F.3d 545, 545 (10th Cir. 1993) (requiring more than mere evidence of pretext); Ellis v. NCNB Tex. Nat'l Bank, 842 F. Supp. 243, 249 (N.D. Tex. 1994) (arguing that the two statements in Hicks cannot be immediately reconciled). But see Anderson v. Baxter Healthcare Corp., 13 F.3d 1120, 1124 n.3 (7th Cir. 1994) (rejecting as dicta a pretext-plus interpretation of Hicks); LeBlanc v. Great Am. Ins. Co., 6 F.3d 836, 843 (1st Cir. 1993) (discussing Hicks and concluding that a pretext-plus showing is not necessary). The Supreme Court recently cleared up this confusion in Reeves v. Sanderson Plumbing Products, No. 99-536, 2000 U.S. LEXIS 3966 (June 12, 2000). There, the Court held that a showing of pretextplus is not required in all cases in order for a plaintiff to avoid a judgment as a matter of law. Rather, the Court stated that "[A] plaintiff's prima facie case, combined with sufficient evidence to find that the employer's asserted justification is false, may permit the trier of fact to conclude that the employer unlawfully discriminated." $I d$. at $* 29$. Thus, while a showing of pretext will not compel a judgment for a plaintiff, that showing may provide a sufficient basis for a fact finder to rule in the plaintiff's favor. Although Reeves was brought under the ADEA, its analysis will apply to cases brought under Title VII because Title VII and the ADEA employ similar analytical frameworks.

For additional analysis of Hicks, see Deborah A. Calloway, St. Mary's Honor Center v. Hicks: Questioning the Basic Assumption, 26 CONN. L. REV. 997, 998 (1994) (arguing that despite the opinion in Hicks in which "the Court joined academics, judges, and a growing segment 
evidence and inferential cases, the plaintiff always bears the burden of proving unlawful intent. ${ }^{251}$

2. Establishing a Prima Facie Case. Under existing frameworks, our hypothetical plaintiff, Carol, can bring a race-based claim asserting that the defendant discriminated against her because she was either White, Black, or multiracial. After McDonald v. Santa $\mathrm{Fe}^{252}$ establishing a prima facie case on the basis of multiracial ancestry should not be problematic. In that case, the Supreme Court held that Whites as well as Blacks may bring race discrimination claims under $\S 1981$ and Title VII. ${ }^{253}$ If both Blacks and Whites are covered under Title VII and $\S 1981$, it would be nonsensical to maintain that multiracial individuals are not. Thus, to make a direct evidence claim, Carol need prove only that the defendant acted on the basis of her multiracial status. ${ }^{254}$ This situation is no different from

of the American population that has come to believe that discrimination no longer exists," discrimination continues to be prevalent in American society; Deborah C. Malamud, The Last Minuet: Disparate Treatment After Hicks, 93 MICH. L. REV. 2229 passim (1995) (defending the Court's reasoning in Hicks and arguing for the abandonment of the McDonnell DouglasBurdine proof structure).

251. See, e.g., Burdine, 450 U.S. at 253, 256; Hicks, 509 U.S. at 511.

252. In McDonald v. Santa Fe Trail Transp. Co., 427 U.S. 273 (1976), two White employees were terminated for stealing company property while a similarly charged Black employee was not. The White employees sued under Title VII and § 1981 alleging race discrimination. See $i d$. at 275-76. The Court held that $\S 1981$ and Title VII prohibit employment discrimination against White individuals as well as people of color. See id. at 280,287. In reaching this conclusion, the Court noted that the statutes on their face are not limited to discrimination against members of any particular race and that the legislative history of both statutes indicate that they were intended to cover both Whites and Blacks. See id. at 278-80, 285-86.

253. See McDonald, 427 U.S. at 281.

254. Proving discrimination on this basis may not be as straightforward as it might seem because the category "multiracial" is ill-defined and its social meaning is unclear. Who exactly falls into in this category, and how does one distinguish its occupants as a practical matter? Are persons with Latino-Black, Asian-Black, or Asian-Latino heritage included? Even if these individuals are considered multiracial, a question remains as to whether discrimination against these individuals arises from the fact of their mixed-racial heritage or from the fact that their identities are comprised of two or more groups against whom discrimination has been directed historically. In other words, does discrimination result from the fact of racial mixture (and all the fears and stereotypical beliefs that practice raises), or does it result from the fact that these individuals belong to historically oppressed groups, or both?

Setting aside the question of Latino-Black, Asian-Black, and Asian-Latino combinations, an additional complexity arises from the fact that multiracial individuals may possess a variety of skin tones. They can appear white as snow, dark as coal, or anywhere between these two extremes. Surely, absent knowledge of their genealogies, all of these individuals will not be discriminated against because of their mixed-racial identities. Notwithstanding the fact that they are all multiracial, the person with a White appearance will be treated as White, and the person 
a White plaintiff proving that she was discriminated against because she is White, or a Black plaintiff asserting that she was discriminated against because she is Black. Of course, as with all direct evidence cases, the defendant may challenge the probative value of the plaintiff's evidence or simply deny the plaintiff's allegations. If the plaintiff's evidence is sufficiently strong and is believed by the factfinder, she may nonetheless prevail. The issue merely turns on the sufficiency of the plaintiff's proof of animus against mixed-race individuals.

If Carol has no proof that the defendant is prejudiced against multiracials per se, she may still be able to establish a race-based claim directly if she can show that the defendant acted out of discriminatory animus towards Whites, or, conversely, towards Blacks. In that scenario, she must show that the defendant regarded her as if she fell within the class against which the defendant is prejudiced. For example, if a White employer refuses to hire Blacks, Carol might argue that the employer regarded her as Black or partly Black. Similarly, if a Black defendant discriminates against Whites, then Carol may assert that the defendant discriminated against her because the defendant regarded her as White or partly White..$^{255}$ In both scenarios, existing doctrine is adequate to address the claim because Carol is simply setting forth a traditional race-based cause of action. She is not arguing that she is distinct or unique, but merely that she was treated like someone within a traditional racial classification and, as a result, differently from someone outside of that classification. This classic model of discrimination is precisely what existing employment discrimination frameworks were designed to handle.

The above analysis produces similar results when one utilizes the inferential framework. Again, under McDonald, Carol should have few problems establishing that she falls within a protected category.

who is dark will be treated as Black. Only those whose skin color does not neatly peg them as falling within an existing racial category will be treated as multiracial.

Carol, the hypothetical plaintiff utilized in this subpart, may be able to circumvent these problems to some extent because she is neither visibly Black nor visibly White. In addition, she may be able to rely upon the history of discrimination against persons whose identity consists of a mixture between a dominant group (i.e., Whites) and a subordinate group (i.e., Blacks).

255. Establishing that the defendant regarded the multiracial person as either Black or White presents the only significant or unique difficulty in this scenario. The one-drop rule may assist the plaintiff in establishing the former. However, that rule may make demonstrating the latter more difficult because historically multiracials have been categorized and treated by society as Black. 
For purposes of this analysis, we must also assume that Carol can show she applied for the position in question and was qualified. The case then turns on whether Carol can establish the fourth prong of the McDonnell Douglas prima facie case, namely that a person outside her protected classification was hired. If the position is filled by someone who is White, Carol should be able to establish a prima facie case by showing that the defendant regarded her as Black or partly Black. The reverse is also true. If the position is filled by someone who is Black, Carol should be able to proceed by showing that the defendant regarded her as White or partly White. Finally, if the position is filled by someone who is either Black or White, Carol may establish an inference of discrimination by arguing that the defendant regarded her as neither White nor Black but as multiracial. ${ }^{256}$

3. The Defendant's Response and the Relevance of Color. As the above analysis demonstrates, setting forth the elements of a prima facie case under the McDonnell Douglas-Burdine-Hicks line of cases

\footnotetext{
256. These claims are very similar to intersectionality claims (i.e., situations in which one element alone would be sufficient to bring the claim, but where two elements combined make things worse than, and perhaps analytically distinct from, claims brought by individuals whose identity consists of only one of these elements). Some courts have recognized intersectionality theory under Title VII in cases where Black women have asserted that a defendant did not discriminate against them because they were Black or because they were women, but because they were Black women. See, e.g., Lam v. University of Haw., 40 F.3d 1551, 1562 (9th Cir. 1994) (discussing discrimination against an Asian-American woman: "where two bases for discrimination exist, they cannot be neatly reduced to distinct components"); Jefferies v. Harris County Community Action Ass'n, 615 F.2d 1025, 1032 (5th Cir. 1980) (finding that "discrimination against black females can exist even in the absence of discrimination against black men or white women”). But see DeGraffenreid v. General Motors Assembly Div., 413 F. Supp. 142, 145 (E.D. Mo. 1976) (finding that the goal of Title VII was not to create a new classification of "black women"). The multiracial identity cases are distinguishable, however, because they do not involve the creation of a third category through the blending of two protected categories (i.e., race and gender). Rather, these cases involve variations within one protected category (i.e., race). For this reason, these cases should be more readily accepted by the courts. For additional discussion of intersectionality theory, see generally Kimberle Crenshaw, Demarginalizing the Intersection of Race and Sex: A Black Feminist Critique of Antidiscrimination Doctrine, Feminist Theory, and Antiracist Politics, 1989 U. CHI. LEgAL F. 139 (examining the tendency in antidiscrimination efforts to treat race and gender as mutually exclusive categories); Kimberle Crenshaw, Mapping the Margins: Intersectionality, Identity Politics and Violence Against Women of Color, 43 STAN. L. REV. 1241 (1991) (critiquing the tendency in identity politics to ignore intragroup differences by examining the race and gender aspects of violence experienced by women of color); Angela P. Harris, Race and Essentialism in Feminist Legal Theory, 42 STAN. L. REV. 581 (1990) (critiquing gender essentialism); Madeline Morris, Stereotypic Alchemy: Transformative Stereotypes and Antidiscrimination Law, 7 YALE L. \& POL'Y REV. 251 (1989) (discussing cases involving a combination of suspect and non-suspect characteristics and arguing that nonsuspect characteristics may be transformed through stereotyping into vehicles of discrimination).
} 
is relatively straightforward. The problem, however, may not be in establishing a prima facie case, but rather in the defendant's response to it. To date, defendants have for the most part accepted plaintiffs' characterizations of their race without question. ${ }^{257}$ In a context where there is growing racial diversity and increasing levels of race-mixing, it is possible that this situation may change. Indeed, one can envision a defendant challenging a light-skinned plaintiff's statement of her race. In this changing context, a defendant may seek to rebut the plaintiff's prima facie showing by arguing that he viewed the plaintiff as falling within the same race as the person hired. Thus, if the person hired is White, the defendant will argue that he viewed the plaintiff as White. Conversely, if the person hired is Black, the defendant will claim that he viewed the plaintiff as Black. If the plaintiff alleges that she is multiracial and the person hired was not, the defendant will maintain that he viewed the plaintiff as falling within the same racial category as the person hired. Thus, if the defendant hired a Black individual, he would argue that he viewed the multiracial plaintiff as Black. If he hired a White person, then he will argue that he viewed the multiracial plaintiff as White.

In all of the above scenarios, if the defendant's arguments are accepted, ${ }^{258}$ the plaintiff is placed in the difficult position of establishing that, notwithstanding the fact that she and the person hired are of the same race, the defendant nonetheless acted with impermissible racial animus towards persons in that class. ${ }^{259}$ Because this assertion is

257. This may be due in part to the widespread acceptance of the one-drop rule. Luther Wright, Jr. details one notable exception involving two twin brothers from Boston who changed their racial classifications from White to Black in order to obtain positions as firefighters. When their classifications were challenged, the brothers were fired for committing racial fraud. See Wright, supra note 237, at 515-16.

258. Of course, the plaintiff may use skin color to challenge the defendant's assertions. That is, she can point to her skin color as evidence that she was not of the same racial group as the person hired. For example, if a defendant alleges that he viewed a multiracial plaintiff as either Black or White, the plaintiff could argue that she was neither visibly Black nor visibly White. The claim, however, is not one based on color. Rather, skin color in this instance acts merely as an indicator of the plaintiff's race and supports a race claim based upon the plaintiff's multiracial status.

259. Some courts have held that in establishing a prima facie case, the plaintiff does not need to prove that the position in question was awarded to a person outside of the plaintiff's protected class. See, e.g., Diaz v. AT\&T, 752 F.2d 1356, 1359-60 (9th Cir. 1985); DeLesstine v. Fort Wayne State Hosp. \& Training Ctr., 682 F.2d 130, 133 (7th Cir. 1982); see also O'Connor v. Consolidated Coin Caterers Corp., 517 U.S. 308, 311 (1996) (holding that an age discrimination claim is not barred simply because the plaintiff and his replacement both fall within the class of individuals protected by the statute). Other courts have suggested that awarding a job to an applicant who is a member of the same protected class as the plaintiff precludes an inference of intentional discrimination. See, e.g., Edwards v. Wallace Community College, 49 F.3d 1517, 1521 
somewhat counterintuitive, and because direct evidence of discriminatory animus towards persons in the same racial category as the person hired is rare, the plaintiff will likely fail. ${ }^{260}$

There may, however, be an option available to the plaintiff that places increased emphasis on color. The plaintiff can assert that even if the defendant saw her as falling within the same racial category as the person hired, the defendant nonetheless treated her differently because of her skin color. In short, the plaintiff can assert a colorism claim. This argument is less counterintuitive because it accounts for a defendant's different view and treatment of two people within the same racial category. Indeed, we see this fact pattern in Sanders $v$. University of the District of Columbia ${ }^{261}$ where a dark-skinned Black employee alleged that her employer discriminated against her in favor of a lighter-skinned Black person. ${ }^{262}$ Although the plaintiff ultimately lost her case, the court allowed the action to proceed on the basis of skin color. ${ }^{263}$

(11th Cir. 1995) (granting summary judgment to a defendant where a discharged AfricanAmerican was replaced by another African-American); Hawkins v. Ceco Corp., 883 F.2d 977, 983-84 (11th Cir. 1989) (reversing the district court's grant of summary judgment for the plaintiff when the plaintiff and the plaintiff's replacement are both Black); Jefferies, 615 F.2d at 1030 (refusing to permit a race-based claim where a discharged plaintiff and a person promoted were both African-American).

260. See supra note 259.

261. No. 88-3614 SS, 1991 U.S. Dist. LEXIS 7448 (D.D.C. June 4, 1991).

262. See id. Also, Walker v. Internal Revenue Serv., 713 F. Supp. 403 (N.D. Ga. 1989), 1illustrates this principle in a slightly different context. That case involved a dark-skinned Black supervisor discriminating against a lighter-skinned Black employee, rather than a supervisor choosing between two employees of the same race. There, as in Sanders, colorism explained how discrimination may occur among individuals of the same race. See id. at 406-07.

263. Another way that a defendant may respond to a plaintiff's prima facie showing is merely a variant of the defense set forth earlier in the text. If the plaintiff alleges that she is multiracial and seeks to establish an inference of discrimination by arguing that the person hired was not multiracial, the defendant may respond that everyone is to some extent multiracial. Thus, the defendant will again argue that there is no difference between the plaintiff and the individual hired. This argument, however, is slightly different from the defense outlined earlier because here the defendant will maintain that there are no racial divisions and that everyone is of the same race. (Indeed, this appears to be the goal of some multiracial category proponents. See supra note 162 and accompanying text.) Assuming that this argument obtains a degree of acceptability at some future point, reliance upon skin color differences and the history of colorism may assist the plaintiff in setting forth a claim. The intraracial colorism cases again will be helpful because they demonstrate that even when racial categories are removed from the equation, distinctions have and will continue to be made on the basis of skin color. Even if everyone is considered to be of the same race (i.e., multiracial), discrimination on the basis of skin color will still occur and should be actionable.

The defendant may also deny knowledge of the plaintiff's mixed racial heritage. In this case, the issue becomes one of proving that discrimination occurred because of the plaintiff's mixed-racial identity. Because people generally do not know the racial ancestry of the individu- 
The analysis thus far has assumed one can neatly place individuals within specific racial categories. This is not always the case. Sometimes it is impossible to determine a person's race, national origin, or ethnicity-especially in a social context where there are a number of racial groups and where race-mixing is on the rise. This fact raises a second way in which a defendant may attempt to rebut a plaintiff's prima facie case: a defendant may argue that he did not view the plaintiff as Black, as White, or as multiracial. Under this "Je ne sais quoi" approach to discrimination, when viewing a very lightcomplected person, the discriminator thinks: "Maybe I cannot specify your race, religion, or national origin. In fact, I may not know who or what you are. However, one thing is clear from your skin color. You are not like me." In other words, notwithstanding the ambiguity concerning the individual's race, that person may still be viewed as an inexorable Other. Not White. Not Black. Just Different.

Is simply being different sufficient to establish a claim? Note that in this fact pattern, absent direct proof of animus, the plaintiff will be unable to counter the defense by arguing that she was discriminated against because she is White, Black, multiracial, or a member of some other racial group. In short, she has no affirmative basis upon which to rest her claim unless she can show a history of discrimination against individuals based solely upon the fact that they are not sufficiently light. That is, she must show a history of discrimination on the basis of skin color.

Establishing the latter proposition is not as challenging as it might initially appear. As I demonstrated in Part II, history is replete with examples of people making distinctions based upon skin color. ${ }^{264}$ Indeed, it could be that the drafters of Title VII, $\S 1981$, and the Fifteenth Amendment were getting at precisely this scenario when they used the phrase "race or color." What contemporary analysts may be missing, but what those legislators probably understood, is that color

\footnotetext{
als whom they encounter in everyday interactions, direct evidence that the defendant was biased against persons of mixed-racial heritage may not be available. In this situation, the only remaining way for the plaintiff to assert her claim is through reliance upon skin color as an indicator of her race.

Finally, a defendant may assert that it is simply bad policy to allow multiracial persons to assert claims; this practice in effect would allow everyone to sue, because everyone is to some extent multiracial (i.e., permit everyone to sue who is of some slightly different color than the person hired). Again, although there may be some validity to this objection, skin color can be used to differentiate racial groups.

264. See supra Part II.
} 
in and of itself (separately from race) can be a basis for distinction. ${ }^{265}$ Thus, the references to "color" in these enactments may have resulted from a legislative recognition that color differences have mattered historically, and that protected classifications are fluid. Being "non-White" or "colored" need not necessarily mean that one fits neatly within any specific racial category. Rather, these terms can mean that a person is subject to discrimination because her skin color indicates that she is different.

This section has explained why legal recognition of color claims is important in order to redress discrimination against lighter-skinned Black or lighter-skinned multiracial individuals. It is, however, important to recall that these individuals are not the only people who may be harmed if courts fail to understand colorism. Darker-skinned Blacks and darker-toned multiracials may be harmed as well. In the existing color hierarchy, lighter-toned persons may be discriminated against because they do not appear "completely" White, but they may also be advantaged because they do not appear "completely" Black. This raises the question of what happens when Whites favor lighterskinned Blacks, or lighter-skinned mixed-race individuals, to the detriment of darker-skinned Blacks or darker-skinned multiracials. Does the mulatto thesis of the nineteenth century (e.g., the notion that lighter-skinned Blacks are superior to their darker brethren) ${ }^{266}$ become the multiracial thesis of the twenty-first century? Because one objective of this Article is to demonstrate how the illusion of racial progress may be overstated if colorism is ignored, it is necessary to consider this issue before concluding.

\section{Colorism and the Quest for Equality of Opportunity}

The color hierarchy in the U.S. is relatively easy to define at its extremes: Whites have generally held the position of privilege, and Blacks have generally been relegated to the bottom. The more difficult question concerns the ways in which benefits are allocated in the middle of the pyramid. As noted above, the essential question for analysis is what happens when Whites (or Blacks) favor lighterskinned Blacks or lighter-skinned mixed-race individuals to the detriment of darker-skinned Blacks? Is there a danger that one segment of the race may move forward while another segment is left behind?

265. See supra Parts I and II.C.

266. See supra notes 92,178 and accompanying text. 
History teaches that these questions are important. As outlined in Section II.B.2, in the late nineteenth and early twentieth centuries, some Black social clubs excluded certain individuals from membership if their skin was too dark. ${ }^{267}$ To some, the presence of these thriving social organizations indicated racial progress. That progress was limited because many Blacks did not have access to the benefits of these organizations because of their darker skin tones. A similar dynamic exists today. Since the enactment of Title VII in 1964, White employers have hired larger numbers of Blacks into positions of prominence and authority. On one level, the increased presence of Blacks in these positions suggests progress. That progress is limited, however, because many of these individuals are lighter-skinned. Thus, although they are willing to hire Blacks, some employers still show a preference for Blacks with lighter skin tones. ${ }^{268}$ This means that while one segment of the Black population benefits professionally, another segment is left behind due to colorism. Until all people are viewed equally, without regard to differences in skin tone, meaningful progress toward equality of opportunity will not occur. One way to begin this forward motion is through legal recognition of color claims.

\section{CONCLUSION}

This Article has probed the legal implications of skin color differences. I have argued that it is important for courts to recognize color differences if we are to succeed in our quest for equality of opportunity both across and within races. Without a firm understanding of colorism and the existing color hierarchy, I fear that, for some people, we will proceed under the illusion, but not the reality, of racial progress.

The most effective way to challenge subordination and the social meaning afforded blackness is to deal directly with the issue of blackness, whether it is presented in a vessel that is the lightest brown or one that is the deepest black. Within this framework, it is unacceptable for Whites to employ disproportionately those individuals who appear closer to White. The goal must be to nudge Whites beyond their fears and prejudices by encouraging them to consider the full array of Black individuals. True progress can only occur when Whites

267. See supra notes $122-25$ and accompanying text.

268. See supra note 10. 
come to appreciate and respect those individuals who are least like themselves.

A similar admonition may be directed to those individuals within the Black community who, either consciously or subconsciously, discriminate against other Blacks on the basis of skin color. Although it is critically important for Blacks to probe the ways in which we are different and how those differences divide us, the solution to our problem is not the construction of additional racial categories that rely heavily on skin color as an indicator and that may inadvertently reinforce colorism. The Black community must not overlook the fact that one of the things that binds Blacks together as a subordinated group is the thread of blackness. This thread results in the oppression of all who share it, regardless of the lightness or darkness of one's skin tone. The focus must not be on whether one has a bit too much or too little melanin in one's skin, but rather the social meaning afforded blackness. Until we change the latter, no person of color will be free.

In conclusion, I am reminded again of the observations of LaShaun, who, at the age of five, will grow up in the twenty-first century. His comments should remind us that the issues addressed in this Article are not merely academic. They are real. Although this generation of five-year-olds is aware of colorism, they are too young to do anything about it. It is therefore our responsibility to ensure that LaShaun, with his rich Michael Jordan brown skin, and the two Aaliyahs of his acquaintance, with their golden brown and chocolate brown skin tones, will not be subject to unequal life opportunities simply because they are different shades of brown. 